\title{
Review \\ Co-Ordination of Mucosal B Cell and CD8 T Cell Memory by Tissue-Resident CD4 Helper T Cells
}

\author{
Young Min Son ${ }^{1,2}$ and Jie Sun ${ }^{1,2,3,4,5, *}$ \\ 1 Division of Pulmonary and Critical Medicine, Department of Medicine, Mayo Clinic, Rochester, MN 55905, \\ USA; son.youngmin@mayo.edu \\ 2 Department of Immunology, Mayo Clinic, Rochester, MN 55905, USA \\ 3 Department of Physiology and Biomedical Engineering, Mayo Clinic, Rochester, MN 55905, USA \\ 4 Carter Immunology Center, University of Virginia, Charlottesville, VA 22908, USA \\ 5 Division of Infectious Disease and International Health, Department of Medicine, University of Virginia, \\ Charlottesville, VA 22908, USA \\ * Correspondence: sun.jie@mayo.edu or js6re@virginia.edu
}

check for updates

Citation: Son, Y.M.; Sun, J.

Co-Ordination of Mucosal B Cell and CD8 T Cell Memory by Tissue-Resident CD4 Helper T Cells. Cells 2021, 10, 2355. https://doi.org/ $10.3390 /$ cells10092355

Academic Editors: Jörg Hamann and Klaas van Gisbergen

Received: 14 July 2021

Accepted: 3 September 2021

Published: 8 September 2021

Publisher's Note: MDPI stays neutral with regard to jurisdictional claims in published maps and institutional affiliations.

Copyright: (c) 2021 by the authors. Licensee MDPI, Basel, Switzerland. This article is an open access article distributed under the terms and conditions of the Creative Commons Attribution (CC BY) license (https:/ / creativecommons.org/licenses/by/ $4.0 /)$.

\begin{abstract}
Adaptive cellular immunity plays a major role in clearing microbial invasion of mucosal tissues in mammals. Following the clearance of primary pathogens, memory lymphocytes are established both systemically and locally at pathogen entry sites. Recently, resident memory CD8 T and $B$ cells ( $T_{R M}$ and $B_{R M}$ respectively), which are parked mainly in non-lymphoid mucosal tissues, were characterized and demonstrated to be essential for protection against secondary microbial invasion. Here we reviewed the current understanding of the cellular and molecular cues regulating CD8 $\mathrm{T}_{\mathrm{RM}}$ and $\mathrm{B}_{\mathrm{RM}}$ development, maintenance and function. We focused particularly on elucidating the role of a novel tissue-resident helper $\mathrm{T}\left(\mathrm{T}_{\mathrm{RH}}\right)$ cell population in assisting $\mathrm{T}_{\mathrm{RM}}$ and $\mathrm{B}_{\mathrm{RM}}$ responses in the respiratory mucosa following viral infection. Finally, we argue that the promotion of $\mathrm{T}_{\mathrm{RH}}$ responses by future mucosal vaccines would be key to the development of successful universal influenza or coronavirus vaccines, providing long-lasting immunity against a broad spectrum of viral strains.
\end{abstract}

Keywords: tissue resident memory T; tissue resident memory B; mucosal immunity; non-lymphoid tissues

\section{Introduction}

A cardinal feature of the adaptive immune system is the ability to develop immunological memory following primary antigenic encounter. Upon microbial invasion, naïve $\mathrm{T}$ cells, primed by antigen-presenting cells (APCs), rapidly undergo massive expansion and effector $\mathrm{T}$ cell differentiation to generate a large pool of antigen-specific effector $\mathrm{T}$ cells for the clearance of invading pathogens. Following pathogen clearance, effector T cells go through a contraction phase, in which majority of the effector T cells undergo apoptosis. The surviving effector cells or memory precursor cells convert into long-term memory $\mathrm{T}$ cells (including both CD4 and CD8 memory) after the contraction phase. Based on their trafficking properties, CD8 memory $\mathrm{T}$ cells can be further categorized into different subsets including central memory $\mathrm{T}\left(\mathrm{T}_{\mathrm{CM}}\right)$, effector memory $\mathrm{T}\left(\mathrm{T}_{\mathrm{EM}}\right)$, peripheral memory $\mathrm{T}\left(\mathrm{T}_{\mathrm{PM}}\right)$ and tissue resident memory $\mathrm{T}\left(\mathrm{T}_{\mathrm{RM}}\right)$ cells [1-5]. $\mathrm{T}_{\mathrm{CM}}$ cells re-circulate through secondary lymphoid organs, $\mathrm{T}_{\mathrm{EM}}$ cells have more broad capacity of mobility between blood and non-lymphoid tissues, while $\mathrm{T}_{\mathrm{PM}}$ cells mainly patrol the blood vessels [4]. In contrast, $\mathrm{T}_{\mathrm{RM}}$ cells are parked in non-lymphoid mucosal tissues and have an impaired capacity to enter re-circulation [6-10]. Following secondary infection with the same virus or viruses bearing conserved $\mathrm{T}$ cell epitopes, memory $\mathrm{T}$ cells are rapidly activated, undergo secondary effector $\mathrm{T}$ cell expansion and differentiation, and mediate prompt pathogen clearance before their systemic dissemination. 
Similarly, naïve B cells can be activated and differentiated into extrafollicular plasmablasts (PBs) or germinal center (GC) B cells in secondary lymphoid organs. The primary extrafollicular PBs have been identified as short-lived antibody secreting cells and may provide a significant source of protective antibodies during microbial infections [11]. GCs are anatomically distinguished into two regions, the dark zone and the light zone [12]. Proliferation and somatic hypermutation of antigen-specific GC B cells occur in the dark zone, following which mutated $B$ cell clones move into the light zone to terminate their differentiation. Within the light zone, B cells internalize antigens which are presented by follicular DCs (FDCs) and interact with follicular helper $\mathrm{T}\left(\mathrm{T}_{\mathrm{FH}}\right)$ cells, a major CD4 T helper subset facilitating B cell-help [13,14]. GC B cells can further differentiate into long-lived plasma cells (LLPCs) or memory B cells (MBCs). LLPCs mediate long-term antibody secretion following primary infection, while MBCs can respond to secondary infection to either differentiate into PBs or re-enter GCs to undergo further affinity maturation [15-17]. Like memory T cells, MBCs can be divided into circulating and tissue-resident $\left(\mathrm{B}_{\mathrm{RM}}\right)$ populations, which reside in mucosal tissues [18].

Despite intensive studies on the cellular and molecular programming of memory lymphocyte generation over the past two decades, our understanding of the mechanisms of memory $\mathrm{T}$ and $\mathrm{B}$ cell maintenance and function, particularly in the mucosal tissues remains limited. Furthermore, little is known regarding the cellular and molecular pathways that may be targeted to simultaneously promote both $\mathrm{B}_{\mathrm{RM}}$ and $\mathrm{T}_{\mathrm{RM}}$ cell responses in the mucosal tissues. Here we will review the current understanding of mechanisms maintaining longterm immunological memory in mucosal tissues, with a focus on the roles of a subset of CD4 $\mathrm{T}$ helper cells, tissue-resident $\mathrm{T}$ helper cells $\left(\mathrm{T}_{\mathrm{RH}}\right)$, in coordinating respiratory mucosal CD8 and B cell memory responses following viral infection.

\section{Tissue-Resident Memory $T\left(T_{R M}\right)$ and $B\left(B_{R M}\right)$ Cells}

\subsection{Generation of CD8 $T_{R M}$ Cells}

CD8 $\mathrm{T}_{\mathrm{RM}}$ cell development is initiated when dendritic cells (DCs), either resident within lymph nodes or following migration from peripheral tissues, prime naïve $\mathrm{T}$ cells into effector CD8 T cells in draining lymph nodes. Antigen-experienced effector CD8 T cells subsequently infiltrate infected tissue to mediate pathogen clearance, after which a subset of CD8 $\mathrm{T}$ cells persists to become $\mathrm{T}_{\mathrm{RM}}$ cells. Interestingly, migrating DCs can also precondition naïve $\mathrm{T}$ cells towards a resident memory $\mathrm{T}$ cell fate via the activation and presentation of transforming growth factor (TGF)- $\beta$ [19]. Furthermore, distinct DC subsets appear to differentially program lymph node homing $\mathrm{T}_{\mathrm{CM}}$, mucosal tissue-homing effector and resident memory $\mathrm{T}$ cells following influenza infection [20]. Therefore, $\mathrm{T}_{\mathrm{RM}}$ cell development may start before the entry of effector $\mathrm{T}$ cells into peripheral organs. Such a notion is supported by recent genetic tracing (using retroviral barcoding) and single cell RNA-seq experiments demonstrating the existence of $\mathrm{T}_{\mathrm{RM}}$ precursors in the circulating effector T cell pool [21].

After their activation in lymphoid organs, effector CD8 T cells enter the circulation and migrate into nonlymphoid tissues to combat invading pathogens. While CD8 $\mathrm{T}_{\mathrm{RM}}$ fate determination can be trained in lymphoid organs, local environment and antigenic re-encounter in the tissue further promote $\mathrm{T}_{\mathrm{RM}}$ development and/or maturation. The differentiation of $\mathrm{T}_{\mathrm{RM}}$ cells can occur independently of local antigen recognition in the peripheral tissue [22-24]; however, local antigenic re-stimulation of effector CD8 T cells in nonlymphoid tissue greatly enhances $T_{R M}$ formation [25-27]. Following the formation of $T_{R M}$ cells, it is believed that $T_{R M}$ maintenance is largely antigen or TCR signaling independent [28]. However, chronic low levels of TCR stimulation due to persistence of antigen following influenza virus infection or following immunization with an adenoviral vector facilitates the accumulation of a protective population of $\mathrm{CD}^{+} 9^{+} \mathrm{CD} 8 \mathrm{~T}_{\mathrm{RM}}$ cells $[29,30]$.

CD69 is a key tissue retention signal of $\mathrm{T}_{\mathrm{RM}}$ cells functioning via the interference of sphingosine-1-phosphate receptor (S1pr1) activity [31,32], thereby restricting cell egress out of the tissue $[31,33]$. Local antigen-restimulation enhances the expression of CD69, 
and concomitantly suppresses S1pr1 and Krüppel-like Factor 2 (KLF2) expression [31,34]. $\mathrm{T}_{\mathrm{RM}}$ cells located within the epithelium further express CD103 (Integrin, alpha E), which binds to E-cadherin expressed on epithelial cells, supporting the accumulation and retention of $T_{R M}$ cells in tissues $[22,35,36]$. In the absence of TGF- $\beta$ signaling, the migrated tissue effector CD8 $\mathrm{T}$ cells fail to develop into $\mathrm{CD} 103^{+} \mathrm{T}_{\mathrm{RM}}$ cells due to lack of $\mathrm{CD} 103$ expression $[35,37,38]$. Interleukin (IL)-15 has been reported to provide a survival signal to memory T cells [39]. Soluble IL-15/IL-15R $\alpha$ complexes in local tissue do not directly induce CXCR3 production in effector cells, but promote the recruitment of CXCR3 ${ }^{+}$antigenspecific effector $\mathrm{T}$ cells to the mucosal area through the downregulation of KLF2 [40]. IL-7 is another important cytokine able to maintain memory $\mathrm{T}$ cell homeostasis through Stat5 signaling [41,42]. Interestingly, while IL-7 and IL-15 can both promote CD8 $\mathrm{T}_{\mathrm{RM}}$ cell maintenance, the homeostatic persistence of skin $\mathrm{CD} 4 \mathrm{~T}_{\mathrm{RM}}$ cells seems mainly dependent on IL-7 produced from hair follicle of skin [43]. TGF- $\beta$ has also been reported to facilitate CD8 $\mathrm{T}_{\mathrm{RM}}$ cell development via down-regulation of T-box transcription factor Eomes and T-bet expression, but residual T-bet activity is critical to maintain responsiveness to IL-15 for CD8 $\mathrm{T}_{\mathrm{RM}}$ cell survival [44]. In the lymphocytic choriomeningitis virus (LCMV) infection model, combination of cytokines including TGF- $\beta$, IL-33 and tumor necrosis factor (TNF) enhances the establishment of CD8 $\mathrm{T}_{\mathrm{RM}}$ cells via the downregulation of S1pr1 [45]. Additionally, proinflammatory cytokines including type I interferons and IL-12 can facilitate the differentiation and accumulation of $\mathrm{CD}_{103^{-}} \mathrm{T}_{\mathrm{RM}}$ cells in the intestine following bacterial infection [46]. Taken together, CD8 $\mathrm{T}_{\mathrm{RM}}$ generation is constantly modulated by a variety of antigenic and environmental factors at various steps of the $\mathrm{T}$ cell life cycle following infection.

\subsection{Transcriptional Regulation of CD8 $T_{R M}$ Development and Persistence}

$\mathrm{T}_{\mathrm{RM}}$ cells exhibit distinct transcriptional profiles when compared to circulating memory $\mathrm{T}$ cells. Several transcription factors have been demonstrated to play important roles in $\mathrm{T}_{\mathrm{RM}}$ cell generation and/or maintenance in peripheral tissues. The two related transcription factors, Blimp-1 and Hobit, cooperatively instruct a tissue-residency transcriptional program in $\mathrm{T}_{\mathrm{RM}}$ cells [10]. Hobit and Blimp-1 directly bind to Klf2 and Tcf7 loci, and then downregulate the expression of Ccr7 and S1pr1. Therefore, they prevent the egress of $T_{R M}$ cells from tissues to blood circulation [10,45]. Runx3 promotes the expression of CD103 and tissue residency-associated gene programs in $\mathrm{T}_{\mathrm{RM}}$ cells, while simultaneously repressing signature genes associated with circulating memory [47]. Runx3 has been reported to enhance the accessibility of the Blimp1 binding region and may facilitate the accessibility of the Hobit binding motif as well [48]. Notch signaling through RBP-jk is also important for the formation of lung $T_{R M}$ cells following influenza virus infection [49]. Of note, TGF- $\beta$ and Notch signaling can be integrated by direct protein-protein interactions of Smad3 and the intracellular domain of Notch (NICD), potentially providing a mechanism underlying the dual requirement of TGF- $\beta$ and Notch in $T_{R M}$ formation [50,51]. Compared to circulating memory $\mathrm{T}$ cells, $\mathrm{T}_{\mathrm{RM}}$ cells highly express the transcription factor Bhlhe 40 and its-associated molecules. Bhlhe40 deficiency caused diminished expression of $\mathrm{T}_{\mathrm{RM}}$ tissue residency-associated genes and molecules involved with $\mathrm{T}_{\mathrm{RM}}$ effector function, largely due to impaired mitochondria fitness and function in Bhlhe40-deficient $\mathrm{T}_{\mathrm{RM}}$ cells [52]. Additionally, the expression of Ahr and NR4A1 is upregulated in $\mathrm{T}_{\mathrm{RM}}$ cells compared to circulating memory CD8 T cells, and their function is required for the maintenance of CD8 $\mathrm{T}_{\mathrm{RM}}$ cells $[37,53,54]$.

\subsection{Development and Maintenance of $B_{R M}$ Cells}

Long-term humoral immunity is generally maintained by LLPCs in the bone marrow (BM) [55], while resting MBCs provide rapid and augmented antibody ( $\mathrm{Ab}$ ) responses upon recognition of same/conserved antigens following secondary infections [56]. The development of both cell types is initiated within the GC structure following help from CD4 T cells [57,58]. Analogous to memory T cells, MBCs can be divided into circulat- 
ing and tissue-resident $\left(\mathrm{B}_{\mathrm{RM}}\right)$ populations. $\mathrm{B}_{\mathrm{RM}}$ cells, mainly residing in non-lymphoid peripheral tissues, express similar tissue-homing and retention molecules as $\mathrm{T}_{\mathrm{RM}}$ cells. For instance, influenza hemagglutinin-specific lung-residing memory B cells [59] highly express CXCR3 and CD69, which are believed to mediate their tissue-homing and residency respectively [59]. In humans, a large number of $\mathrm{CD} 19^{+} \mathrm{CD} 27^{+} \mathrm{CD} 45 \mathrm{RB}^{+} \mathrm{CD} 69^{+} \mathrm{B}_{\mathrm{RM}}$ cells have been identified in the gut and tonsil but not in blood and BM [60].

Compared to circulating memory $\mathrm{B}$ cells, $\mathrm{B}_{\mathrm{RM}}$ cells facilitate rapid recall responses in the tissue and may exhibit unique phenotypical and functional markers. For instance, mouse lung $B_{R M}$ expresses lower CD73 than those MBCs in the blood or spleen [18]. Furthermore, respiratory $B_{R M}$ cells reside in specific niches; in the upper respiratory tract, these are located in the nasal-associated lymphoid tissue (NALT) whereas they are found in the inducible bronchus associated lymphoid tissue (iBALT) in the lower respiratory tract [61-63]. Like $\mathrm{T}_{\mathrm{RM}}$ cell development, $\mathrm{B}_{\mathrm{RM}}$ cells are thought to be initiated following CD4 T cell help in secondary lymphoid organs, but the full establishment of $B_{R M}$ cells in peripheral tissue requires local antigenic re-encounter [18]. Additionally, GC B cells of the lung, particularly those developed early post infection, may also supply $B_{R M}$ precursors following influenza virus infection $[64,65]$. Thus, optimal $B_{R M}$ development is subject to both distal regulation in the lymphoid organs and local regulation inside the peripheral tissue.

The functions of $B_{R M}$ cells have not been fully elucidated yet. However, $B_{R M}$ cells are thought to provide immediate and rapid responses against pathogen entry at mucosal tissues [66]. MBCs re-activated by pathogens have been reported to either differentiate into antibody secreting cells (ASCs) or undergo expansion and affinity maturation through reentry of GC [67-69]. Lung influenza-specific $B_{R M}$ cells are reported to directly differentiate into ASCs upon recognition of the same viral antigen during influenza reinfection, but do not re-enter the GC structure, thereby facilitating viral clearance in the respiratory mucosa [18]. Interestingly, influenza-specific lung $B_{R M}$ cells developed from local GC responses possess high cross-reactivity to viral escape mutants [64,65], and thus they may exert broadly protective function against distinct viral strains. Furthermore, $B_{R M}$ cells located in tertiary lymphoid structures are also considered potential APCs and may facilitate $T$ cell responses in the respiratory mucosa [66,70]. In addition to influenza infection, antigen-specific $B_{\mathrm{RM}}$ cells are also developed following pneumococcal infection, although tertiary lymphoid organ (i.e., iBALT) formation was not observed. Importantly, depletion of PD-L2 ${ }^{+}$lung $\mathrm{B}_{\mathrm{RM}}$ cells caused diminished bacterial clearance and reduction of pneumococcus-reactive antibodies in the lung upon pneumococcal reinfection, suggesting that lung $B_{\mathrm{RM}}$ cells are vital for pulmonary antibacterial immunity [71].

\section{Characteristic Tissue-Resident CD4 T Cells}

\subsection{Heterogeneity of Tissue-Resident CD4 T Cells}

The mechanisms underlying $\mathrm{CD} 4 \mathrm{~T}_{\mathrm{RM}}$ cell formation and maintenance are relatively less well-studied compared to those of CD8 $\mathrm{T}_{\mathrm{RM}}$ cells. Similar to CD8 $\mathrm{T}_{\mathrm{RM}}$ cells, activated CD4 $T$ cells migrate into peripheral tissues and survive long term to form CD4 $T_{R M}$ cells. CD4 $\mathrm{T}_{\mathrm{RM}}$ cells share tissue-residency markers like CD69 and CXCR6 with CD8 $\mathrm{T}_{\mathrm{RM}}$ cells [72,73]. Like mouse $\mathrm{T}_{\mathrm{RM}}$ cells, human CD4 $\mathrm{T}_{\mathrm{RM}}$ cells also express high level of CD69 while circulating CD4 memory T cells do not $[73,74]$. Unlike effector CD8 T cells, which mainly produce type 1 cytokines such as IFN- $\gamma$ and TNF, effector CD4 T cells can be subdivided into distinct subtypes based on their cytokine production including IFN- $\gamma$ producing Thelper type $1\left(\mathrm{~T}_{\mathrm{H}} 1\right)$, IL-4/5/13-producing T helper type $2\left(\mathrm{~T}_{\mathrm{H}} 2\right)$, IL-17 producing $\mathrm{T}$ helper type $17\left(\mathrm{~T}_{\mathrm{H}} 17\right)$ and IL-21 producing follicular helper $\mathrm{T}\left(\mathrm{T}_{\mathrm{FH}}\right)$ cells $[75,76]$. In the murine model, tissue-resident $T_{H} 1\left(T_{H} 1 T_{R M}\right)$ cells have been reported following respiratory infection. Lung $\mathrm{T}_{\mathrm{H}} 1 \mathrm{~T}_{\mathrm{RM}}$ cells developed following influenza virus infection rapidly produce IFN- $\gamma$ and contribute to host protection upon secondary infection $[77,78] . \mathrm{T}_{\mathrm{H}} 1 \mathrm{~T}_{\mathrm{RM}}$ cells have also been identified in the skin and gut following Leishmania and Listeria infections, respectively [79-81]. $\mathrm{T}_{\mathrm{H}} 1 \mathrm{~T}_{\mathrm{RM}}$ cells generated by tuberculosis are characterized by high 
expression of CXCR3 and low expression of KLRG1 [82,83]. For long-term maintenance in tissues, $\mathrm{T}_{\mathrm{H}} 1 \mathrm{~T}_{\mathrm{RM}}$ cells express high levels of CD11a and VLA-1 to promote their retention and survival in the tissue niche [84]. $\mathrm{T}_{\mathrm{H}} 2 \mathrm{~T}_{\mathrm{RM}}$ are usually generated during allergic responses or parasitic infections. In a house dust mite (HDM)-induced allergic asthma model, it was shown that lung $\mathrm{T}_{\mathrm{RM}}$ cells and circulating $\mathrm{T}_{\mathrm{H}} 2$ memory cells cooperatively induce allergic inflammation in the lung [85]. During Heligmosomoides polygyrus infection, $\mathrm{T}_{\mathrm{H}} 2 \mathrm{~T}_{\mathrm{RM}}$ cells are formed and persist in the lamina propria and peritoneal cavity (PC). Interestingly, $\mathrm{T}_{\mathrm{H}} 2 \mathrm{~T}_{\mathrm{RM}}$ cells in both sites produce general $\mathrm{T}_{\mathrm{H}} 2$ cytokines like IL-4, IL-5 and IL-13 following TCR restimulation, but only $\mathrm{T}_{\mathrm{H}} 2 \mathrm{~T}_{\mathrm{RM}}$ in PC can respond with IL-33 and IL-7 upon TCR-independent restimulation [86]. $\mathrm{T}_{\mathrm{H}} 17 \mathrm{~T}_{\mathrm{RM}}$ can be generated following Candida albicans (C. albicans) infection in both mouse and human subjects. Both circulating $\mathrm{T}_{\mathrm{H}} 17$ memory cells and $\mathrm{T}_{\mathrm{H}} 17 \mathrm{~T}_{\mathrm{RM}}$ cells are important to clear the $C$. albicans upon rechallenge, but $\mathrm{T}_{\mathrm{H}} 17 \mathrm{~T}_{\mathrm{RM}}$ cells are more effective in rapidly clearing the pathogens [87]. In Mycobacterium tuberculosis (M. tuberculosis)-infected patients, lung CD4 $\mathrm{T}_{\mathrm{RM}}$ cells produce IL-17 following antigenic stimulation, which along with IL-17 and IL-2 produced by $\mathrm{T}_{\mathrm{H}} 17$ $\mathrm{T}_{\mathrm{RM}}$ cells suppress the growth of $M$. tuberculosis in 3D culture system [88].

Like effector $T_{R M}$ subsets, Foxp-3 expressing regulatory $T$ cells $\left(T_{R E G}\right.$ ) cells in the tissue can express CD69 and possess tissue-residency features. Importantly, tissue-resident $\mathrm{T}_{\text {REG }}$ cells may provide an essential check point for the pathogenic activities of $\mathrm{T}_{\mathrm{RM}}$ cells. Chronic exposure of Aspergillus fumigatus induces the formation of CD69hi $C D 103^{\text {lo }} \mathrm{CD} 4 \mathrm{~T}_{\mathrm{RM}}$ cells, which contribute to pulmonary fibrosis. At the same time, $\mathrm{CD} 69^{\text {hi }} \mathrm{CD} 103^{\text {hi }}$ Foxp $3^{+} \mathrm{T}_{\mathrm{REG}}$ cells constrain the effects of pathogenic $\mathrm{CD} 103^{\text {lo }} \mathrm{CD} 4 \mathrm{~T}_{\mathrm{RM}}$ cells and limit their fibrogenic potential [89]. Furthermore, lung tissue $\mathrm{T}_{\mathrm{REG}}$ cells produce amphiregulin (Areg), an epidermal growth factor receptor ligand, to repair tissue damage following influenza virus infection [90].

Common gamma-chain cytokines such as IL-2, IL-15 and IL-7 are essential to develop or maintain memory CD4 T cells. The cytokines have recently been reported to be essential in the formation of CD4 $\mathrm{T}_{\mathrm{RM}}$ cells. Autocrine IL-2 signaling in infiltrating tissue CD4 T cells is critical for the generation of $\mathrm{T}_{\mathrm{H}} 1 \mathrm{~T}_{\mathrm{RM}}$ cells in the lung [91]. In the absence of IL-2R signaling, $\mathrm{T}_{\mathrm{H}} 1 \mathrm{~T}_{\mathrm{RM}}$ cells induced by intranasal LCMV infection or allergic $\mathrm{T}_{\mathrm{H}} 2 \mathrm{~T}_{\mathrm{RM}}$ cells generated following HDM administration fail to be maintained over the long-term within the lung [92,93]. High levels of IL-7 receptor are expressed by lung $\mathrm{T}_{\mathrm{RM}}$ cells compared to circulating memory T cells, and IL-7 treatment in vivo induces the infiltration of circulating CD4 T cells into the lung to form $\mathrm{T}_{\mathrm{RM}}$ cells [94]. Similarly, IL-15 supports the development of lung CD4 $\mathrm{T}_{\mathrm{RM}}$ post influenza virus infection [95].

\subsection{Niches of Local CD4 T Cells}

Tissue-resident CD4 T cells are typically located under epithelial layers and inside the ectopic lymphoid structures with stromal cells or APCs [96]. In the skin, particularly the dermis, lymphoid structures are generated around hair follicles with CD4 T cells and CD11b ${ }^{+}$DCs $[97,98]$. CCL5, IL-7 and IL-15 which are produced in the local environment, promote the maintenance of $\mathrm{CD} 4 \mathrm{~T}_{\mathrm{RM}}$ clusters in skin [43,97]. The female reproductive tract (FRT) is a mucosal tissue that consists of two different areas, including the upper FRT and the lower FRT. Mucosa-associated lymphoid tissues (MALT) composed of B cells and CD4 $\mathrm{T}_{\mathrm{RM}}$ cells are typically developed in the lamina propria (LP) of the upper FRT. Furthermore, CD4 T cells can migrate to upper FRT following skin infection with Chlamydia to form a cluster with $B$ and CD8 $T_{R M}$ cells $[99,100]$. In the lower FRT, there are no MALT at steady state, but $C D 4 T_{R M}$ cells along with $B$ cells, $D C$ and macrophages form clusters during the clearance of an intravaginal HSV-2 infection. APCs including B cells and DCs facilitate CD4 $\mathrm{T}_{\mathrm{RM}}$ maintenance in the lower FRT area [101,102].

The respiratory tract is an entry site for many viruses including influenza, respiratory syncytial virus (RSV) or severe acute respiratory syndrome coronavirus 2 (SARS-CoV-2). The respiratory tract can also be divided into two compartments, the upper respiratory tract (URT) and the lower respiratory tract (LRT). Nasal-associated lymphoid tissues (NALT) 
localized in URT contain CD4 $\mathrm{T}_{\mathrm{RM}}$ cells [96]. iBALTs within the LRT are the primary niches for lung CD4 $\mathrm{T}_{\mathrm{RM}}$ cells $[64,103,104]$ following influenza infection, which is in contrast to those influenza-specific $\mathrm{CD} 8 \mathrm{~T}_{\mathrm{RM}}$ cells that are primarily localized to the site of regeneration in the lung parenchyma following tissue injury $[33,105]$.

\section{CD4 Help and Memory B and CD8 T Cell Responses}

\subsection{CD4 Help and Memory B Cell Generation}

CXCR5 and PD-1 expressing CD4 helper T cells that localize in the GC are termed $\mathrm{T}_{\mathrm{FH}}$ cells [106]. $\mathrm{T}_{\mathrm{FH}}$ cells express the transcription factor BCL6, the cytokine IL-21 and provide $\mathrm{CD} 4 \mathrm{~T}$ cell help to $\mathrm{B}$ cells in the GC. Therefore, $\mathrm{T}_{\mathrm{FH}}$ cells are important in the development of long-term humoral immunity mediated by MBCs and plasma cells (PCs), which are mainly derived from GC B cells. $\mathrm{T}_{\mathrm{FH}}$ cell formation goes through two sequential steps [58], including $\mathrm{T}$ cell priming first at the T cell zone by DCs followed by subsequent maturation in the B cell zone through interactions with B cells via ICOS-ICOS-L and MHC II-TCR. Cytokines including IL-6, IL-12 and IL-21 can promote $\mathrm{T}_{\mathrm{FH}}$ formation, while IL-2 and type I IFNs potently suppress $\mathrm{T}_{\mathrm{FH}}$ cell generation $[58,107-110]$.

BCL6 ${ }^{\text {lo }}$ CD69hi GC-B cells that express high levels of IRF4 favor the differentiation into PCs [111], while CCR6 has been reported as a marker for memory B cell precursors [112]. Recently, IL-9 producing $\mathrm{T}_{\mathrm{FH}}$ cells have been reported to support the development of GC-derived memory precursor B cells and subsequent optimal formation of memory B cells [113]. Interestingly, the strength of the interaction between GC $B$ and $T_{\mathrm{FH}}$ cells affects the formation of memory B cells. Cells prone to enter the memory B cell pool typically exhibit lower B cell receptor affinity and express high levels of Bach2, which has been found to be inversely correlated with the strength of help provided by $\mathrm{T}_{\mathrm{FH}}$ cells [114].

\subsection{CD4 T Cell Help and CD8 Memory T Cell Responses}

CD4 $\mathrm{T}$ cell help plays an indispensable role in the primary CD8 T cell response in certain infection and/or immunization models [115-117]. CD4 help is critical for licensing APCs to support optimal CD8 T cell activation and differentiation [118]. In this case, interaction of CD4 T cells with APCs promotes the expression of key co-stimulatory molecules and pro-inflammatory cytokines required for maximal CD8 T cell activation $[119,120]$. Additionally, cytokines produced by CD4 T cells such as IL-2 can facilitate CD8 T cell expansion and effector generation [121]. However, in infectious models that generate strong inflammatory responses such as influenza infection, the primary CD8 T cell responses are largely independent of CD4 T cell help, potentially due to the direct activation of DCs by robust TLR signaling [122].

In contrast to the context-dependent roles of CD4 $\mathrm{T}$ cells in helping primary CD8 T cell responses, CD4 T cell help is uniformly required for the generation, maintenance and/or recall responses of memory CD8 $\mathrm{T}$ cell responses. To this end, CD4 T cell-derived IL-2 has been linked to promote secondary CD8 T cell responses [123,124]. Furthermore, CD4 T cells could license APCs to produce IL-15, a key cytokine involved in memory CD8 T cell formation and/or maintenance [120]. Additionally, $\mathrm{T}_{\mathrm{REG}}$ cell-derived IL-10 has been shown to promote memory CD8 T cell maturation during the contraction phase via the suppression of pro-inflammatory cytokine production by DCs [125]. Lastly, activated CD4 $\mathrm{T}$ cells may directly interact with effector CD8 T cells via CD40-CD40L to facilitate memory CD8 T cell differentiation [126]. Regardless of the molecular cues provided by CD4 T cells for CD8 memory $\mathrm{T}$ cell generation, un-helped CD8 T cells are prone to apoptosis and could undergo activation-induced cell death, possibly through the induction of TRAIL expression [116,127].

Besides the role of CD4 help in the generation of circulating effector and memory $\mathrm{T}$ cells, recent advances have suggested that CD4 $\mathrm{T}$ cell help is important in mucosal $\mathrm{T}$ cell responses and the induction of CD8 $\mathrm{T}_{\mathrm{RM}}$ responses. During HSV-2 infection, CD4 T cells control the migration of CTL through the secretion of IFN- $\gamma$ and induction of local chemokine secretion in the infected tissue [128]. During influenza infection, CD4 T cell 
help occurs at the priming phase of $\mathrm{T}$ cell responses, which is critical for the development of CD8 $\mathrm{T}_{\mathrm{RM}}$ cells in the lung. In the absence of CD4 T cell help, CD8 T cells failed to properly localize to the lung niches supporting optimal $\mathrm{T}_{\mathrm{RM}}$ development. Furthermore, un-helped CD8 T cells exhibited high levels of T-bet expression, which interferes with CD103 expression through the modulation of TGF- $\beta$ responsiveness [129]. These results demonstrate the importance of CD4 helper T cells in the formation of CD8 $\mathrm{T}_{\mathrm{RM}}$ cell precursors, while the role of $\mathrm{CD} 4 \mathrm{~T}$ cell help in $\mathrm{CD} 8 \mathrm{~T}_{\mathrm{RM}}$ cell maintenance has not been elucidated.

\section{CD4 Tissue-Resident Helper Cells Coordinate $T_{R M}$ and $B_{R M}$ Responses in the Respiratory Mucosa}

\section{1. $T_{F H}$-Like Cells in Non-Lymphoid Tissues}

Although $\mathrm{T}_{\mathrm{FH}}$ cells are generally localized in secondary lymphoid organs, $\mathrm{T}_{\mathrm{FH}}$-like cells can be found in circulation or in non-lymphoid tissues $[130,131]$. In human joint tissue from patients with rheumatoid arthritis, a subset of $\mathrm{T}_{\mathrm{FH}}$-like peripheral helper CD4 $T$ cells $\left(\mathrm{T}_{\mathrm{PH}}\right)$ that exhibits potent $\mathrm{B}$ cell help activities was recently identified [132]. Phenotypically, $\mathrm{T}_{\mathrm{PH}}$ cells share key signatures with $\mathrm{T}_{\mathrm{FH}}$ cells including high levels of PD-1 expression, production of IL-21, expression of BCL6 and the lack of expression of other T helper lineage cytokines and/or transcription factors. However, $\mathrm{T}_{\mathrm{PH}}$ cells have distinct features from $\mathrm{T}_{\mathrm{FH}}$ cells, including the lack or low expression of CXCR5 expression and the high expression of Blimp1. $\mathrm{T}_{\mathrm{PH}}$ or $\mathrm{T}_{\mathrm{PH}}$-like cells have been observed in tertiary lymphoid structures developed in various inflammatory conditions such as rheumatoid arthritis (RA), Crohn's disease and malignancy [133-136].

Tissue-infiltrating $\mathrm{T}_{\mathrm{FH}}$-like cells have also been reported in animal models, particularly in inflammatory lung conditions $[130,137,138]$. In an HDM-induced allergic model, IL-21 producing $\mathrm{T}_{\mathrm{FH}}$-like cells, which lack expression of CXCR5, were found in the inflamed lung [137]. Furthermore, IL-21 produced by those $\mathrm{T}_{\mathrm{FH}}$-like cells promotes lung $\mathrm{T}_{\mathrm{H}} 2$ responses, eosinophil recruitment and HDM-specific IgG1 production [137]. Like human $\mathrm{T}_{\mathrm{PH}}$ cells, antigen-specific $\mathrm{T}_{\mathrm{FH}}$-like cells expressed high levels of IL-21, PD-1 and ICOS, but lower BCL6, CXCR5 than lymph node $\mathrm{T}_{\mathrm{FH}}$ cells. In a model of LPS-adjuvanted airway immunization model, lung-infiltrating $\mathrm{T}$ cells were identified to exhibit follicular helper-like properties including the potential to provide help to naive $\mathrm{B}$ cells. These $\mathrm{T}_{\mathrm{FH}}$-like cells did not express classical $\mathrm{T}_{\mathrm{FH}}$ markers, CXCR5 and PD-1, but expressed molecules involved in $\mathrm{B}$ cell help including CD40L and IL-21. As such, these $\mathrm{T}_{\mathrm{FH}}$-like cells supported the generation of GC B cells in situ within the lung [138]. Together, these data demonstrate the presence of a $\mathrm{T}_{\mathrm{FH}}$-like $\mathrm{CD} 4$ helper population in non-lymphoid tissues, but the roles of these cells in regulating local B and CD8 memory T cells have not been examined. Furthermore, the cellular and molecular cues regulating the development of $\mathrm{T}_{\mathrm{FH}}$-like cells in peripheral tissue are still unknown.

\subsection{Identification of Tissue-Resident Helper T Cells in the Lung}

As stated above, many questions remain unanswered regarding the nature and function of $\mathrm{T}_{\mathrm{FH}}$-like cells in non-lymphoid tissues. First, are the $\mathrm{T}_{\mathrm{FH}}$-like cells tissue-resident in non-lymphoid tissues? Second, what are the mechanisms underlying the phenotypic similarity and difference between conventional $\mathrm{T}_{\mathrm{FH}}$ cells in secondary lymphoid organs and $\mathrm{T}_{\mathrm{FH}}$-like cells in the non-lymphoid tissues? Third, what are the physiological functions of $\mathrm{T}_{\mathrm{FH}}$-like cells in regulating local tissue immunity?

Using single-cell RNA sequencing, our group and the group of Carolyn King recently found that lung parenchyma CD4 $\mathrm{T}$ cells exhibit marked heterogeneity following primary influenza virus infection. In addition to traditional $\mathrm{T}_{\mathrm{H} 1}$-like $\mathrm{T}_{\mathrm{RM}}, \mathrm{T}_{\mathrm{H} 17}$-like $\mathrm{T}_{\mathrm{RM}}$ cells and tissue $\mathrm{T}_{\mathrm{REG}}$ cells, lung parenchyma $\mathrm{CD} 4 \mathrm{~T}$ cell compartment contains a $\mathrm{T}_{\mathrm{FH}}$-like $\mathrm{CD} 4 \mathrm{~T}$ cell population [64,104]. This $\mathrm{T}_{\mathrm{FH}}$-like cell population appeared around two weeks after infection, following clearance of infectious virus and persisted through the memory phase, i.e., more than two months after infection. The $\mathrm{T}_{\mathrm{FH}}$-like cells expressed modest $\mathrm{BCL} 6$ 
and CXCR5, and high levels of PD-1, IL-21 and FR4, thus exhibiting key $\mathrm{T}_{\mathrm{FH}}$ phenotypic markers. Compared to splenic $\mathrm{T}_{\mathrm{FH}}$ cells, these $\mathrm{T}_{\mathrm{FH}}$-like cells had higher levels of the tissue residency gene program, the transcription factor Bhlhe 40 and peripheral homing marker CXCR6, thus exhibiting $T_{R M}$ features. Indeed, using parabiosis, we demonstrated that these tissue $\mathrm{T}_{\mathrm{FH}}$-like cells were tissue-resident. Furthermore, the optimal responses of these lung $\mathrm{T}_{\mathrm{FH}}$-like cells required the presence of both BCL6 and Bhlhe40, demonstrating the dual requirement of $\mathrm{T}_{\mathrm{FH}}$ and $\mathrm{T}_{\mathrm{RM}}$ gene programs for its development [52]. Thus, these tissue $\mathrm{T}_{\mathrm{FH}}$-like cells appear to be a "hybrid" population of $\mathrm{T}_{\mathrm{FH}}$ and $\mathrm{T}_{\mathrm{RM}}$ cells. Based on the transcriptional, phenotypic and non-migratory characteristics, we termed these cells tissue-resident helper $\mathrm{T}$ cells $\left(\mathrm{T}_{\mathrm{RH}}\right)$.

\subsection{Promotion of Local B Cell Immunity by $T_{R H}$ Cells}

Like $\mathrm{T}_{\mathrm{FH}}$ cells, $\mathrm{T}_{\mathrm{RH}}$ cells express key $\mathrm{B}$ cell helping molecules including ICOS, CD40L and/or IL-21. As such, $\mathrm{T}_{\mathrm{RH}}$ ablation severely impaired lung GC B cell responses and iBALT formation (Figure 1).

\section{Non-Lymphoid Tissue - Lower Respiratory Tract}
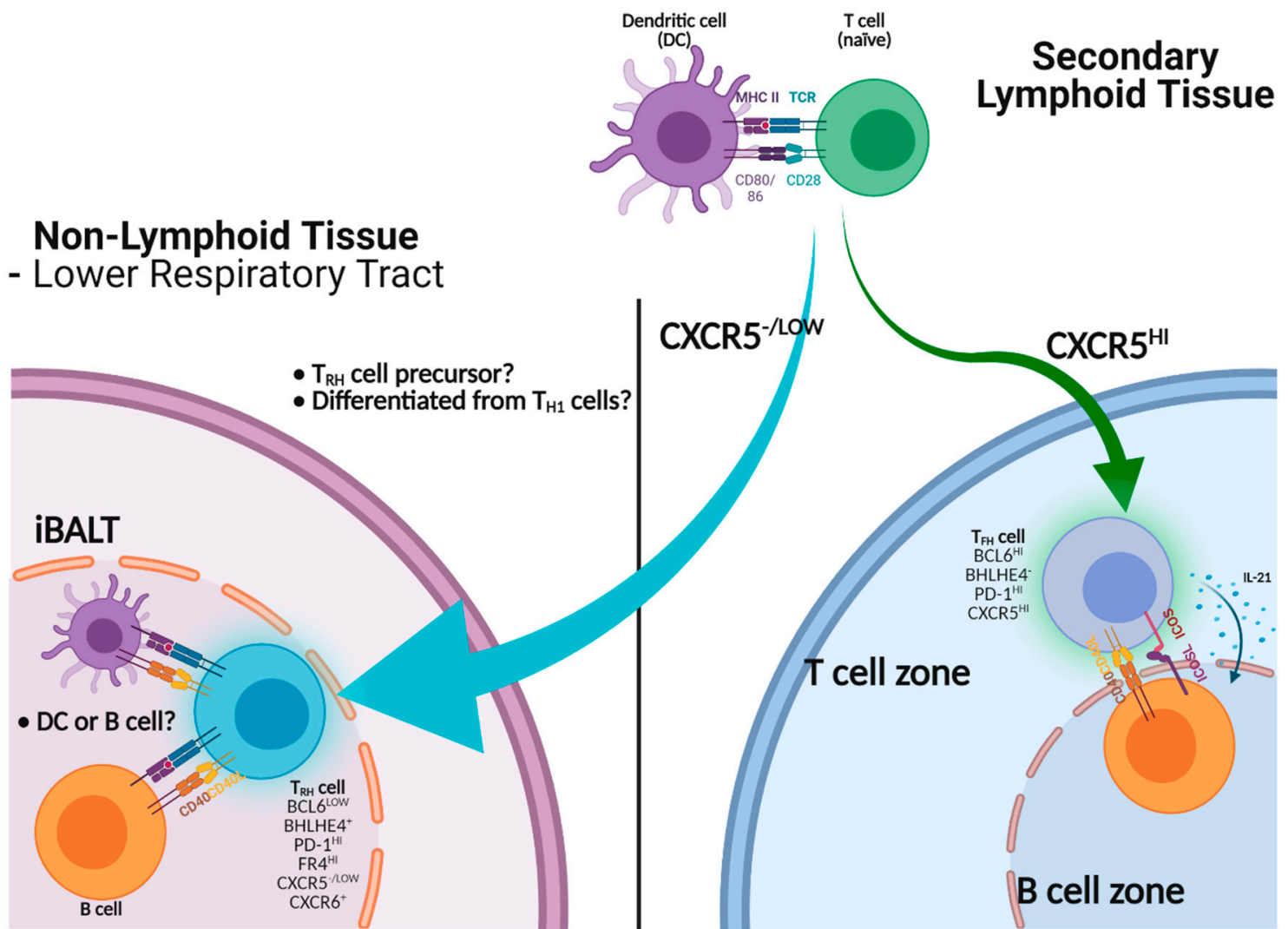

Figure 1. Help of $\mathrm{B}$ cell immunity by $\mathrm{T}_{\mathrm{RH}}$ or $\mathrm{T}_{\mathrm{FH}}$ cells. Activated CD4 $\mathrm{T}$ cells migrate into the $\mathrm{B}$ cell zone to become mature CXCR5 ${ }^{\text {hi }} \mathrm{T}_{\mathrm{FH}}$ cells to help B cells via CD40-CD40L, ICOS-ICOS-L interactions and cytokines including IL-21. $\mathrm{T}_{\mathrm{RH}}$ precursors, which express low levels of CXCR5, can infiltrate into non-lymphoid tissues such as the lung. $\mathrm{T}_{\mathrm{RH}}$ precursors adapt to the lung environment to become mature $\mathrm{T}_{\mathrm{RH}}$ cells, thereby assisting $\mathrm{B}$ cell immunity in situ through the expression of CD40L.

As discussed above, lung GC contributes to respiratory $B_{R M}$ development and iBALT is likely a niche for lung $B_{R M}$ cells. Consequently, we found that $T_{R H}$ ablation impaired influenza-specific lung $B_{R M}$ responses but not systemic $B$ cell memory. Those $B_{R M}$ cells that are cross-reactive to viral escape mutants were also diminished following $\mathrm{T}_{\mathrm{RH}}$ depletion, suggesting that $\mathrm{T}_{\mathrm{RH}}$ cells may be key for the development of broadly reactive memory $\mathrm{B}$ cells against heterologous influenza strains [64]. In a subsequent study, Swarnalekha et al. further showed that lung antigen-specific ASCs were significantly decreased in $\mathrm{T}_{\mathrm{RH}}$ cell- 
ablated mice following influenza virus rechallenge [104], demonstrating the importance of $\mathrm{T}_{\mathrm{RH}}$ cells in mediating memory $\mathrm{B}$ cell recall responses.

These studies have established the critical roles of $\mathrm{T}_{\mathrm{RH}}$ in assisting the development local effector and memory B cell responses during both primary and recall responses following influenza virus infection. Swarnalekha et al. also showed that $\mathrm{T}_{\mathrm{RH}}$ cells are localized within the iBALT structure, while $\mathrm{T}_{\mathrm{H} 1} \mathrm{~T}_{\mathrm{RM}}$ cells are more concentrated outside or at the border of the iBALT, suggesting that $T_{R H}$ cells may lend their help to $B$ cells within the tertiary lymphoid organ. Similar to $\mathrm{T}_{\mathrm{FH}}$ cells, $\mathrm{T}_{\mathrm{RH}}$ development requires $\mathrm{B}$ cells and is facilitated by prolonged antigen presentation [104]. Interestingly, we found that the B cell helper function of $\mathrm{T}_{\mathrm{RH}}$ cells was dependent on the CD40-CD40L interaction, but not IL-21, which is required for $\mathrm{T}_{\mathrm{FH}}$-mediated $\mathrm{B}$ cell help. Thus, $\mathrm{T}_{\mathrm{RH}}$ and $\mathrm{T}_{\mathrm{FH}}$ cells may have both common and distinct $\mathrm{B}$ cell help mechanisms.

\section{4. $T_{R H}$ Cells and the Maintenance of CD8 $T_{R M}$ Cells}

During experiments dissecting the physiologic function of $\mathrm{T}_{\mathrm{RH}}$ cells, perhaps the biggest surprise came from the observation that $T_{R H}$ depletion selectively diminished a population of CD8 $\mathrm{T}_{\mathrm{RM}}$ cells specific to the influenza Nucleoprotein peptide 366-374 $\left(\mathrm{NP}_{366-374}\right)$ [64]. Previously, we found that $\mathrm{NP}_{366-374}$ specific $\mathrm{CD} 8 \mathrm{~T}_{\mathrm{RM}}$ cells receive persistent low-levels of antigenic stimulation at the memory stage, due to the delayed clearance of the NP antigen [29]. These $\mathrm{NP}_{366-374} \mathrm{~T}_{\mathrm{RM}}$ cells expressed high levels of PD-1 but low levels of CD103 and possessed features of both memory and exhausted-like T cells, compared to those of conventional $\mathrm{CD} 9^{+} \mathrm{CD}_{103}{ }^{+} \mathrm{T}_{\mathrm{RM}}$ cells [29]. Importantly, the $\mathrm{NP}_{366-374}$ $\mathrm{T}_{\mathrm{RM}}$ cells offered critical protective function against secondary heterologous viral infection. Conversely, the blockade of PD-1 activity at the memory stage selectively expanded these $T_{R M}$ cells and promoted the lung pathological responses [29]. Thus, those PD-1 ${ }^{\mathrm{Hi}}$ exhausted-like $\mathrm{T}_{\mathrm{RM}}$ cells are important in maintaining the balance between $\mathrm{T}_{\mathrm{RM}}$-mediated protection and pathology. When $\mathrm{T}_{\mathrm{RH}}$ cells were ablated, we found that the quantity of $\mathrm{NP}_{366-374} \mathrm{~T}_{\mathrm{RM}}$ cells were significantly decreased, but not those of conventional $\mathrm{T}_{\mathrm{RM}}$ cells restricted to other peptides such as the influenza polymerase peptide 224-233 ( $\left.\mathrm{PA}_{224-233}\right)$. Consequently, $\mathrm{T}_{\mathrm{RM}}$-mediated protective immunity against heterologous viral reinfection was diminished following $T_{R H}$ ablation. These data suggest that $T_{R H}$ cells are vital for maintaining protective $T_{R M}$ responses following influenza infection.

As discussed above, BCL6-expressing $\mathrm{T}_{\mathrm{RH}}$ cells are located inside the iBALT [104]. Previous results have shown that CD8 $\mathrm{T}_{\mathrm{RM}}$ cells are found outside the iBLAT (nearby border area), most of which are particularly localized near repair associated memory depots (RAMD) [105]. It is thus intriguing that $\mathrm{T}_{\mathrm{RH}}$ cells facilitate $\mathrm{NP}_{366-374} \mathrm{~T}_{\mathrm{RM}}$ maintenance in a contact-independent way, as $\mathrm{T}_{\mathrm{RH}}$ and $\mathrm{T}_{\mathrm{RM}}$ are likely localized in different lung niches. IL-21 has been showed to be a critical molecule mediating CD4 T cell help for optimal $\mathrm{CD} 8 \mathrm{~T}$ cell responses during chronic viral infection [64]. Since $\mathrm{NP}_{366-374} \mathrm{~T}_{\mathrm{RM}}$ cells exhibit features of exhausted CD8 T cells from chronic viral infection, we hypothesized that IL-21 produced by $\mathrm{T}_{\mathrm{RH}}$ cells is critical to sustain $\mathrm{NP}_{366-374} \mathrm{~T}_{\mathrm{RM}}$ responses (Figure 2).

Indeed, IL-21R blockade following influenza viral clearance led to diminished $\mathrm{NP}_{366-374}$ $\mathrm{T}_{\mathrm{RM}}$ responses. Furthermore, IL-21 is mainly produced by $\mathrm{T}_{\mathrm{RH}}$ cells in the lung following influenza infection [64]. These data suggest that $\mathrm{T}_{\mathrm{RH}}$ cells maintain optimal $\mathrm{T}_{\mathrm{RM}}$-mediated protective immunity through IL-21, which may act over a relatively longer range to provide help to CD8 $\mathrm{T}_{\mathrm{RM}}$ cells compared to their help to $\mathrm{B}$ cells, which is mediated by cell surface molecule CD40L. Consistent with our observations, antigen-specific IL-21 producing CD4 $\mathrm{T}$ cells have also been identified in the brain of mice after polyomavirus (MuPyV) infection. The IL-21-producing CD4 $\mathrm{T}$ cells express high-affinity TCRs and $\mathrm{T}_{\mathrm{FH}}$ cell markers like PD-1 and CXCR5. Importantly, in the absence of IL-21 signaling, brain CD8 T cells failed to differentiate into $T_{R M}$ cells with sufficient CD103 expression [139]. Although it is not known whether these brain $\mathrm{T}_{\mathrm{FH}}$-like cells had $\mathrm{T}_{\mathrm{RM}}$ features (thus being equivalent to brain $\mathrm{T}_{\mathrm{RH}}$ cells), these data do suggest that tissue $\mathrm{T}_{\mathrm{FH}}$-like cells may be required for sustaining maximal CD8 $\mathrm{T}_{\mathrm{RM}}$ responses in a broad spectrum of nonlymphoid tissues. 


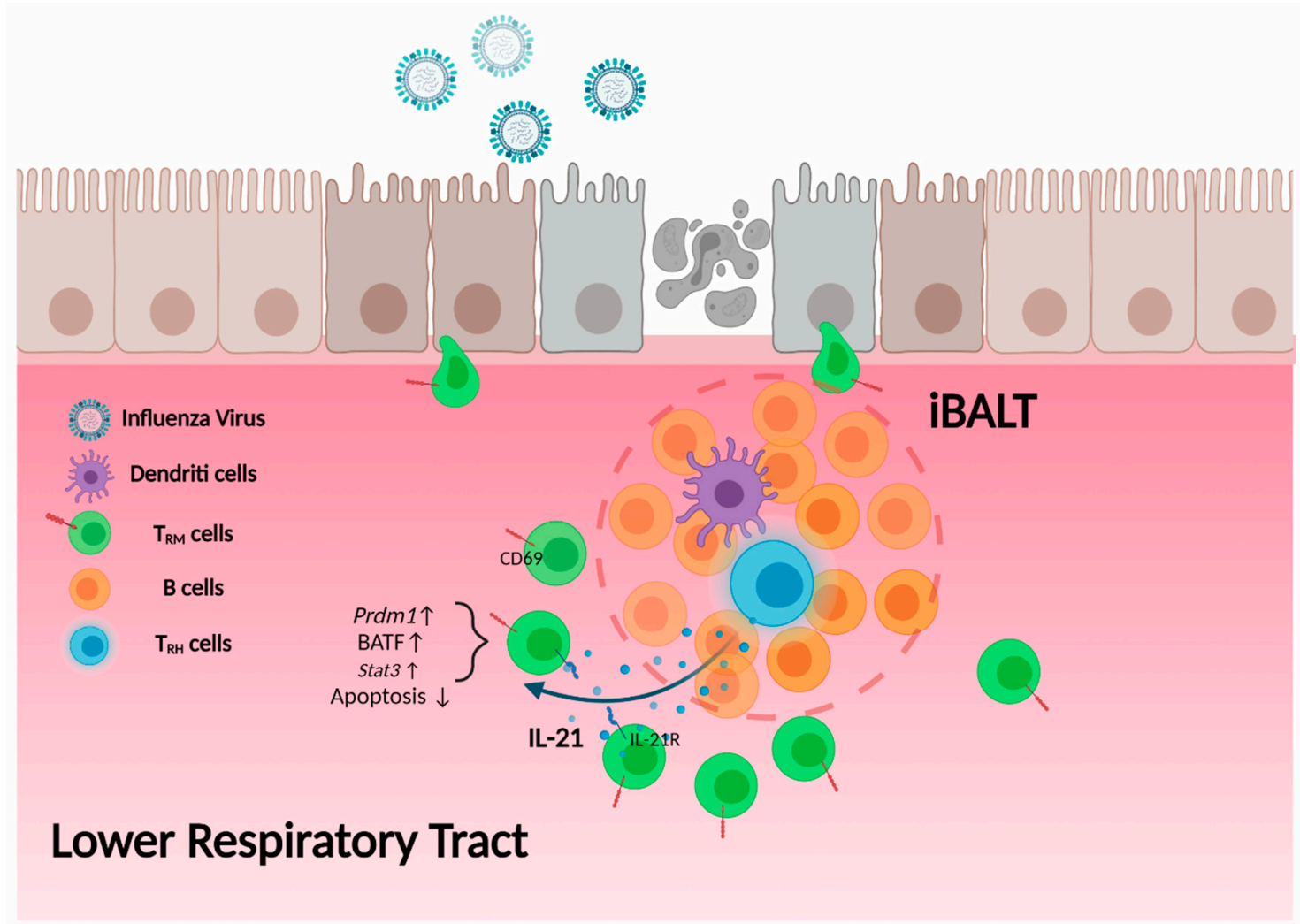

Figure 2. $\mathrm{T}_{\mathrm{RH}}$ cell help to CD8 $\mathrm{T}_{\mathrm{RM}}$ cells. $\mathrm{T}_{\mathrm{RH}}$ cells, which localize within the iBALT, secrete IL-21. Influenza $\mathrm{NP}_{366-374-}$ specific CD8 $\mathrm{T}_{\mathrm{RM}}$ cells are located outside but near the border of iBALT structure and express high levels of IL-21 receptor. IL-21 secreted from $T_{R H}$ cells promotes the expression of Blimp-1 (Prdm1), BATF and other molecules in CD8 $T_{R M}$ cells, thereby maintaining $\mathrm{NP}_{366-374}$-specific $\mathrm{T}_{\mathrm{RM}}$ cell retention and survival in the lung.

\section{6. $T_{\mathrm{RH}}$ cells as a Potential Target for Mucosal Vaccine against Respiratory Viral Infection}

Lower respiratory tract viral infections represent a major public health challenge and economic burden worldwide. In a matter of months, SARS-CoV2 infection completely altered societal norms, stagnated economies, and overwhelmed healthcare infrastructures across the globe. Annual influenza epidemics cause up to 500,000 deaths globally and there exists an ever-present threat of the emergence of a pandemic influenza strain in the future [140]. Vaccination still remains the best approach to mitigate disease burden caused by respiratory viral infection. Current vaccines against influenza and SARS-CoV2 infections are mainly administered via the systemic route, which induces strong systemic but typically weak mucosal immune responses [141-144].

The efficacy of the current influenza vaccines in providing protection against infection is still relatively limited, even in the years when the predicted vaccine strains perfectly match circulating strains. Furthermore, due to escape mutants generated by the rapid mutation of influenza virus, the current influenza vaccines require an annual update. To this end, the "holy grail" of influenza vaccine development is to create a universal influenza vaccine that can provide long-lasting and cross-reactive immunity against a broad-spectrum of influenza viral strains. It is argued that an "all-inclusive" approach, i.e., the induction of concerted immune responses, including both strong memory $\mathrm{B}$ and $\mathrm{T}$ cell responses, is needed to provide protective immunity against a wide ranges of influenza viruses [145]. Due to the nature of mucosal $B_{R M}$ and $T_{R M}$ responses, a mucosal vaccine that can induce strong cross-reactive $B_{R M}$ and $T_{R M}$ responses is more than likely a viable strategy for universal vaccine development. Since $\mathrm{T}_{\mathrm{RH}}$ cells are able to provide local "help" for the development and/or maintenance of robust mucosal B and CD8 T cell responses, 
we argue that the promotion of $\mathrm{T}_{\mathrm{RH}}$ responses by future mucosal vaccines will be key to develop successful universal influenza vaccines.

The current mRNA vaccines against SARS-CoV2 infection induce robust systemic immunity, thereby providing strong protection against viral infection and severe disease development [146]. It is still unknown whether SARS-CoV2 mRNA vaccines are able to induce effective mucosal antibody and/or B/T cell responses in humans. However, based on data generated using mouse immunization models, it seems unlikely that systemic immunization of mRNA-encoded antigens would generate strong mucosal memory $\mathrm{T}$ and B cells against SARS-CoV2 infection. Despite the current success of SARS-CoV2 mRNA vaccines, emerging data have suggested that the mRNA vaccine induced protective immunity may be dampened against newer variants of the SARS-CoV2 virus, particularly the delta strain $[147,148]$. Thus, there is still room for improvement with the development of better and broader protective SARS-CoV2 vaccines. To this end, a SARS-CoV2 vaccine capable of inducing both strong humoral and cellular (i.e., $\mathrm{B}_{\mathrm{RM}}$ and/or $\mathrm{T}_{\mathrm{RM}}$ development) immunity in the respiratory mucosa may ultimately meet the needs for long-lasting protection against a variety of SARS-CoV2 strains. In this case, the induction of robust respiratory $\mathrm{T}_{\mathrm{RH}}$ responses again may be a pre-requirement for the success of such a vaccine.

\section{Concluding Remarks}

Memory lymphocytes establish tissue residency in the respiratory tract following pulmonary viral infection and/or mucosal vaccination. Here we reviewed the developmental cues and molecular mechanisms regulating the formation of CD4 and CD8 $T_{R M}$ and $B_{R M}$ cells in mucosal tissues. We put forward a $\mathrm{T}_{\mathrm{RH}^{-}}$-centric model, modulating the concerted development of mucosal B and T cell memory responses following mucosal infection and immunization. We believe that the induction of a strong $\mathrm{T}_{\mathrm{RH}}$ response is key to protective mucosal immunity generated by future universal vaccine candidates. Conversely, dysregulated $\mathrm{T}_{\mathrm{RH}}$ responses may contribute to the development pulmonary inflammation in various disease conditions including asthma or long-term chronic sequelae following respiratory viral infections $[149,150]$.

Author Contributions: Y.M.S. and J.S. designed the contents and wrote the manuscript. All authors have read and agreed to the published version of the manuscript.

Funding: This study was funded by the U.S. NIH R01s AI112844, AI147394, AI154598 and AG047156 (to J.S.).

Institutional Review Board Statement: Not applicable.

Informed Consent Statement: Not applicable.

Data Availability Statement: Not applicable.

Acknowledgments: We thank Harish Narasimhan for critical reading of the manuscript.

Conflicts of Interest: The authors declare no conflict of interest.

\section{References}

1. Sallusto, F.; Lenig, D.; Förster, R.; Lipp, M.; Lanzavecchia, A. Two subsets of memory T lymphocytes with distinct homing potentials and effector functions. Nature 1999, 401, 708-712. [CrossRef]

2. Farber, D.L.; Ahmadzadeh, M. Dissecting the complexity of the memory T cell response. Immunol. Res. 2002, 25, 247-259. [CrossRef]

3. Mueller, S.N.; Gebhardt, T. Carbone FR, Heath WR. Memory T cell subsets, migration patterns, and tissue residence. Annu. Rev. Immunol. 2013, 31, 137-161. [CrossRef] [PubMed]

4. Martin, M.D.; Badovinac, V.P. Defining Memory CD8 T Cell. Front. Immunol. 2018, 9, 2692. [CrossRef] [PubMed]

5. Gerlach, C.; Moseman, E.A.; Loughhead, S.M.; Alvarez, D.; Zwijnenburg, A.J.; Waanders, L.; Garg, R.; de la Torre, J.C.; von Andrian, U.H. The Chemokine Receptor CX3CR1 Defines Three Antigen-Experienced CD8 T Cell Subsets with Distinct Roles in Immune Surveillance and Homeostasis. Immunity 2016, 45, 1270-1284. [CrossRef] [PubMed]

6. Masopust, D.; Soerens, A.G. Tissue-Resident T Cells and Other Resident Leukocytes. Annu. Rev. Immunol. 2019, 37, 521-546. [CrossRef] [PubMed] 
7. Gebhardt, T.; Wakim, L.M.; Eidsmo, L.; Reading, P.C.; Heath, W.R.; Carbone, F.R. Memory T cells in nonlymphoid tissue that provide enhanced local immunity during infection with herpes simplex virus. Nat. Immunol. 2009, 10, 524-530. [CrossRef] [PubMed]

8. Steinbach, K.; Vincenti, I.; Merkler, D. Resident-Memory T Cells in Tissue-Restricted Immune Responses. For Better or Worse? Front. Immunol. 2018, 9, 2827. [CrossRef] [PubMed]

9. Grau-Expósito, J.; Sánchez-Gaona, N.; Massana, N.; Suppi, M.; Astorga-Gamaza, A.; Perea, D.; Rosado, J.; Falcó, A.; Kirkegaard, C.; Torrella, A.; et al. Peripheral and lung resident memory T cell responses against SARS-CoV-2. Nat. Commun. 2021, 12, 3010. [CrossRef]

10. Mackay, L.K.; Minnich, M.; Kragten, N.A.; Liao, Y.; Nota, B.; Seillet, C.; Zaid, A.; Man, K.; Preston, S.; Freestone, D.; et al. Hobit and Blimp1 instruct a universal transcriptional program of tissue residency in lymphocytes. Science 2016, 352, 459-463. [CrossRef]

11. Blanchard-Rohner, G.; Pulickal, A.S.; Jol-van der Zijde, C.M.; Snape, M.D.; Pollard, A.J. Appearance of peripheral blood plasma cells and memory B cells in a primary and secondary immune response in humans. Blood 2009, 114, 4998-5002. [CrossRef] [PubMed]

12. De Silva, N.S.; Klein, U. Dynamics of B cells in germinal centres. Nat. Rev. Immunol. 2015, 15, 137-148. [CrossRef] [PubMed]

13. Liu, D.; Xu, H.; Shih, C.; Wan, Z.; Ma, X.; Ma, W.; Luo, D.; Qi, H. T-B-cell entanglement and ICOSL-driven feed-forward regulation of germinal centre reaction. Nature 2015, 517, 214-218. [CrossRef]

14. Han, S.; Hathcock, K.; Zheng, B.; Kepler, T.B.; Hodes, R.; Kelsoe, G. Cellular interaction in germinal centers. Roles of CD40 ligand and B7-2 in established germinal centers. J. Immunol. 1995, 155, 556-567.

15. Zuccarino-Catania, G.V.; Sadanand, S.; Weisel, F.J.; Tomayko, M.M.; Meng, H.; Kleinstein, S.H.; Good-Jacobson, K.L.; Shlomchik, M.J. CD80 and PD-L2 define functionally distinct memory B cell subsets that are independent of antibody isotype. Nat. Immunol. 2014, 15, 631-637. [CrossRef] [PubMed]

16. Dugan, H.L.; Guthmiller, J.J.; Arevalo, P.; Huang, M.; Chen, Y.Q.; Neu, K.E.; Henry, C.; Zheng, N.Y.; Lan, L.Y.; Tepora, M.E.; et al. Preexisting immunity shapes distinct antibody landscapes after influenza virus infection and vaccination in humans. Sci. Transl. Med. 2020, 12, eabd3601. [CrossRef]

17. Mesin, L.; Schiepers, A.; Ersching, J.; Barbulescu, A.; Cavazzoni, C.B.; Angelini, A.; Okada, T.; Kurosaki, T.; Victora, G.D. Restricted Clonality and Limited Germinal Center Reentry Characterize Memory B Cell Reactivation by Boosting. Cell 2020, 180, 92-106.e11. [CrossRef]

18. Allie, S.R.; Bradley, J.E.; Mudunuru, U.; Schultz, M.D.; Graf, B.A.; Lund, F.E.; Randall, T.D. The establishment of resident memory $\mathrm{B}$ cells in the lung requires local antigen encounter. Nat. Immunol. 2019, 20, 97-108. [CrossRef]

19. Mani, V.; Bromley, S.K.; Äijö, T.; Mora-Buch, R.; Carrizosa, E.; Warner, R.D.; Hamze, M.; Sen, D.R.; Chasse, A.Y.; Lorant, A.; et al. Migratory DCs activate TGF- $\beta$ to precondition naïve CD8(+) T cells for tissue-resident memory fate. Science 2019, 366, eaav5728. [CrossRef]

20. Kim, T.S.; Gorski, S.A.; Hahn, S.; Murphy, K.M.; Braciale, T.J. Distinct dendritic cell subsets dictate the fate decision between effector and memory CD8(+) T cell differentiation by a CD24-dependent mechanism. Immunity 2014, 40, 400-413. [CrossRef]

21. Kok, L.; Dijkgraaf, F.E.; Urbanus, J.; Bresser, K.; Vredevoogd, D.W.; Cardoso, R.F.; Perié, L.; Beltman, J.B.; Schumacher, T.N. A committed tissue-resident memory T cell precursor within the circulating CD8+ effector T cell pool. J. Exp. Med. 2020, 217, e20191711. [CrossRef]

22. Casey, K.A.; Fraser, K.A.; Schenkel, J.M.; Moran, A.; Abt, M.C.; Beura, L.K.; Lucas, P.J.; Artis, D.; Wherry, E.J.; Hogquist, K.; et al. Antigen-independent differentiation and maintenance of effector-like resident memory T cells in tissues. J. Immunol. 2012, 188, 4866-4875. [CrossRef] [PubMed]

23. Mackay, L.K.; Stock, A.T.; Ma, J.Z.; Jones, C.M.; Kent, S.J.; Mueller, S.N.; Heath, W.R.; Carbone, F.R.; Gebhardt, T. Long-lived epithelial immunity by tissue-resident memory T (TRM) cells in the absence of persisting local antigen presentation. Proc. Natl. Acad. Sci. USA 2012, 109, 7037-7042. [CrossRef] [PubMed]

24. Holz, L.E.; Prier, J.E.; Freestone, D.; Steiner, T.M.; English, K.; Johnson, D.N.; Mollard, V.; Cozijnsen, A.; Davey, G.M.; Godfrey, D.I.; et al. CD8(+) T Cell Activation Leads to Constitutive Formation of Liver Tissue-Resident Memory T Cells that Seed a Large and Flexible Niche in the Liver. Cell Rep. 2018, 25, 68-79.e4. [CrossRef] [PubMed]

25. Khan, T.N.; Mooster, J.L.; Kilgore, A.M.; Osborn, J.F.; Nolz, J.C. Local antigen in nonlymphoid tissue promotes resident memory CD8+ T cell formation during viral infection. J. Exp. Med. 2016, 213, 951-966. [CrossRef]

26. Fernandez-Ruiz, D.; Ng, W.Y.; Holz, L.E.; Ma, J.Z.; Zaid, A.; Wong, Y.C.; Lau, L.S.; Mollard, V.; Cozijnsen, A.; Collins, N.; et al. Liver-Resident Memory CD8(+) T Cells Form a Front-Line Defense against Malaria Liver-Stage Infection. Immunity 2016, 45, 889-902. [CrossRef]

27. Wakim, L.M.; Woodward-Davis, A.; Bevan, M.J. Memory T cells persisting within the brain after local infection show functional adaptations to their tissue of residence. Proc. Natl. Acad. Sci. USA 2010, 107, 17872-17879. [CrossRef]

28. Wijeyesinghe, S.; Beura, L.K.; Pierson, M.J.; Stolley, J.M.; Adam, O.A.; Ruscher, R.; Steinert, E.M.; Rosato, P.C.; Vezys, V.; Masopust, D. Expansible residence decentralizes immune homeostasis. Nature 2021, 592, 457-462. [CrossRef]

29. Wang, Z.; Wang, S.; Goplen, N.P.; Li, C.; Cheon, I.S.; Dai, Q.; Huang, S.; Shan, J.; Ma, C.; Ye, Z.; et al. PD-1(hi) CD8(+) resident memory T cells balance immunity and fibrotic sequelae. Sci. Immunol. 2019, 4, eaaw1217. [CrossRef] 
30. Uddbäck, I.; Cartwright, E.K.; Schøller, A.S.; Wein, A.N.; Hayward, S.L.; Lobby, J.; Takamura, S.; Thomsen, A.R.; Kohlmeier, J.E.; Christensen, J.P. Long-term maintenance of lung resident memory T cells is mediated by persistent antigen. Mucosal Immunol. 2021, 14, 92-99. [CrossRef]

31. Mackay, L.K.; Braun, A.; Macleod, B.L.; Collins, N.; Tebartz, C.; Bedoui, S.; Carbone, F.R.; Gebhardt, T. Cutting edge. CD69 interference with sphingosine-1-phosphate receptor function regulates peripheral T cell retention. J. Immunol. 2015, 194, $2059-2063$. [CrossRef]

32. Shiow, L.R.; Rosen, D.B.; Brdicková, N.; Xu, Y.; An, J.; Lanier, L.L.; Cyster, J.G.; Matloubian, M. CD69 acts downstream of interferon-alpha/beta to inhibit S1P1 and lymphocyte egress from lymphoid organs. Nature 2006, 440, 540-544. [CrossRef]

33. Takamura, S.; Yagi, H.; Hakata, Y.; Motozono, C.; McMaster, S.R.; Masumoto, T.; Fujisawa, M.; Chikaishi, T.; Komeda, J.; Itoh J.; et al. Specific niches for lung-resident memory CD8+ T cells at the site of tissue regeneration enable CD69-independent maintenance. J. Exp. Med. 2016, 213, 3057-3073. [CrossRef]

34. Carlson, C.M.; Endrizzi, B.T.; Wu, J.; Ding, X.; Weinreich, M.A.; Walsh, E.R.; Wani, M.A.; Lingrel, J.B.; Hogquist, K.A.; Jameson, S.C. Kruppel-like factor 2 regulates thymocyte and T-cell migration. Nature 2006, 442, 299-302. [CrossRef] [PubMed]

35. Lee, Y.T.; Suarez-Ramirez, J.E.; Wu, T.; Redman, J.M.; Bouchard, K.; Hadley, G.A.; Cauley, L.S. Environmental and antigen receptor-derived signals support sustained surveillance of the lungs by pathogen-specific cytotoxic T lymphocytes. J. Virol. 2011, 85, 4085-4094. [CrossRef] [PubMed]

36. Thom, J.T.; Weber, T.C.; Walton, S.M.; Torti, N.; Oxenius, A. The Salivary Gland Acts as a Sink for Tissue-Resident Memory CD8(+) T Cells, Facilitating Protection from Local Cytomegalovirus Infection. Cell Rep. 2015, 13, 1125-1136. [CrossRef]

37. Mackay, L.K.; Rahimpour, A.; Ma, J.Z.; Collins, N.; Stock, A.T.; Hafon, M.L.; Vega-Ramos, J.; Lauzurica, P.; Mueller, S.N.; Stefanovic, T.; et al. The developmental pathway for CD103(+)CD8+ tissue-resident memory T cells of skin. Nat. Immunol. 2013, 14, 1294-1301. [CrossRef]

38. Sheridan, B.S.; Pham, Q.M.; Lee, Y.T.; Cauley, L.S.; Puddington, L.; Lefrançois, L. Oral infection drives a distinct population of intestinal resident memory CD8(+) T cells with enhanced protective function. Immunity 2014, 40, 747-757. [CrossRef] [PubMed]

39. Schluns, K.S.; Williams, K.; Ma, A.; Zheng, X.X.; Lefrançois, L. Cutting edge: Requirement for IL-15 in the generation of primary and memory antigen-specific CD8 T cells. J. Immunol. 2002, 168, 4827-4831. [CrossRef] [PubMed]

40. Sowell, R.T.; Goldufsky, J.W.; Rogozinska, M.; Quiles, Z.; Cao, Y.; Castillo, E.F.; Finnegan, A.; Marzo, A.L. IL-15 Complexes Induce Migration of Resting Memory CD8 T Cells into Mucosal Tissues. J. Immunol. 2017, 199, 2536-2546. [CrossRef]

41. Burchill, M.A.; Goetz, C.A.; Prlic, M.; O’Neil, J.J.; Harmon, I.R.; Bensinger, S.J.; Turka, L.A.; Brennan, P.; Jameson, S.C.; Farrar, M.A. Distinct effects of STAT5 activation on CD4+ and CD8+ T cell homeostasis: Development of CD4+CD25+ regulatory T cells versus CD8+ memory T cells. J. Immunol. 2003, 171, 5853-5864. [CrossRef]

42. Hand, T.W.; Cui, W.; Jung, Y.W.; Sefik, E.; Joshi, N.S.; Chandele, A.; Liu, Y.; Kaech, S.M. Differential effects of STAT5 and PI3K/AKT signaling on effector and memory CD8 T-cell survival. Proc. Natl. Acad. Sci. USA 2010, 107, 16601-16606. [CrossRef] [PubMed]

43. Adachi, T.; Kobayashi, T.; Sugihara, E.; Yamada, T.; Ikuta, K.; Pittaluga, S.; Saya, H.; Amagai, M.; Nagao, K. Hair follicle-derived IL-7 and IL-15 mediate skin-resident memory T cell homeostasis and lymphoma. Nat. Med. 2015, 21, 1272-1279. [CrossRef] [PubMed]

44. Mackay, L.K.; Wynne-Jones, E.; Freestone, D.; Pellicci, D.G.; Mielke, L.A.; Newman, D.M.; Braun, A.; Masson, F.; Kallies, A.; Belz, G.T.; et al. T-box Transcription Factors Combine with the Cytokines TGF-beta and IL-15 to Control Tissue-Resident Memory T Cell Fate. Immunity 2015, 43, 1101-1111. [CrossRef] [PubMed]

45. Skon, C.N.; Lee, J.Y.; Anderson, K.G.; Masopust, D.; Hogquist, K.A.; Jameson, S.C. Transcriptional downregulation of S1pr1 is required for the establishment of resident memory CD8+ T cells. Nat. Immunol. 2013, 14, 1285-1293. [CrossRef]

46. Bergsbaken, T.; Bevan, M.J.; Fink, P.J. Local Inflammatory Cues Regulate Differentiation and Persistence of CD8(+) Tissue-Resident Memory T Cells. Cell Rep. 2017, 19, 114-124. [CrossRef]

47. Grueter, B.; Petter, M.; Egawa, T.; Laule-Kilian, K.; Aldrian, C.J.; Wuerch, A.; Ludwig, Y.; Fukuyama, H.; Wardemann, H.; Waldschuetz, R.; et al. Runx3 regulates integrin alpha E/CD103 and CD4 expression during development of CD4-/CD8+ T cells. J. Immunol. 2005, 175, 1694-1705. [CrossRef]

48. Wang, D.; Diao, H.; Getzler, A.J.; Rogal, W.; Frederick, M.A.; Milner, J.; Yu, B.; Crotty, S.; Goldrath, A.W.; Pipkin, M.E. The Transcription Factor Runx3 Establishes Chromatin Accessibility of cis-Regulatory Landscapes that Drive Memory Cytotoxic T Lymphocyte Formation. Immunity 2018, 48, 659-674.e6. [CrossRef]

49. Hombrink, P.; Helbig, C.; Backer, R.A.; Piet, B.; Oja, A.E.; Stark, R.; Brasser, G.; Jongejan, A.; Jonkers, R.E.; Nota, B.; et al. Programs for the persistence, vigilance and control of human CD8(+) lung-resident memory T cells. Nat. Immunol. 2016, 17, 1467-1478. [CrossRef]

50. Elyaman, W.; Bassil, R.; Bradshaw, E.M.; Orent, W.; Lahoud, Y.; Zhu, B.; Radtke, F.; Yagita, H.; Khoury, S.J. Notch receptors and Smad3 signaling cooperate in the induction of interleukin-9-producing T cells. Immunity 2012, 36, 623-634. [CrossRef]

51. Blokzijl, A.; Dahlqvist, C.; Reissmann, E.; Falk, A.; Moliner, A.; Lendahl, U.; Ibáñez, C.F. Cross-talk between the Notch and TGF-beta signaling pathways mediated by interaction of the Notch intracellular domain with Smad3. J. Cell Biol. 2003, 163, 723-728. [CrossRef] [PubMed] 
52. Li, C.; Zhu, B.; Son, Y.M.; Wang, Z.; Jiang, L.; Xiang, M.; Ye, Z.; Beckermann, K.E.; Wu, Y.; Jenkins, J.W.; et al. The Transcription Factor Bhlhe40 Programs Mitochondrial Regulation of Resident CD8(+) T Cell Fitness and Functionality. Immunity 2019, 51, 491-507.e7. [CrossRef] [PubMed]

53. Zaid, A.; Mackay, L.K.; Rahimpour, A.; Braun, A.; Veldhoen, M.; Carbone, F.R.; Manton, J.H.; Heath, W.R.; Mueller, S.N. Persistence of skin-resident memory T cells within an epidermal niche. Proc. Natl. Acad. Sci. USA 2014, 111, 5307-5312. [CrossRef]

54. Boddupalli, C.S.; Nair, S.; Gray, S.M.; Nowyhed, H.N.; Verma, R.; Gibson, J.A.; Abraham, C.; Narayan, D.; Vasquez, J.; Hedrick, C.C.; et al. ABC transporters and NR4A1 identify a quiescent subset of tissue-resident memory T cells. J. Clin. Investig. 2016, 126, 3905-3916. [CrossRef]

55. Halliley, J.L.; Tipton, C.M.; Liesveld, J.; Rosenberg, A.F.; Darce, J.; Gregoretti, I.V.; Popova, L.; Kaminiski, D.; Fucile, C.F.; Albizua, I.; et al. Long-Lived Plasma Cells Are Contained within the CD19(-)CD38(hi)CD138(+) Subset in Human Bone Marrow. Immunity 2015, 43, 132-145. [CrossRef]

56. Tarlinton, D.; Good-Jacobson, K. Diversity among memory B cells: Origin, consequences, and utility. Science 2013, 341, 1205-1211. [CrossRef]

57. Akkaya, M.; Kwak, K.; Pierce, S.K. B cell memory: Building two walls of protection against pathogens. Nat. Rev. Immunol. 2020, 20, 229-238. [CrossRef]

58. Crotty, S. T Follicular Helper Cell Biology. A Decade of Discovery and Diseases. Immunity 2019, 50, 1132-1148. [CrossRef] [PubMed]

59. Onodera, T.; Takahashi, Y.; Yokoi, Y.; Ato, M.; Kodama, Y.; Hachimura, S.; Kurosaki, T.; Kobayashi, K. Memory B cells in the lung participate in protective humoral immune responses to pulmonary influenza virus reinfection. Proc. Natl. Acad. Sci. USA 2012, 109, 2485-2490. [CrossRef]

60. Weisel, N.M.; Weisel, F.J.; Farber, D.L.; Borghesi, L.A.; Shen, Y.; Ma, W.; Luning Prak, E.T.; Shlomchik, M.J. Comprehensive analyses of B-cell compartments across the human body reveal novel subsets and a gut-resident memory phenotype. Blood 2020, 136, 2774-2785. [CrossRef] [PubMed]

61. Boyden, A.W.; Legge, K.L.; Waldschmidt, T.J. Pulmonary infection with influenza A virus induces site-specific germinal center and T follicular helper cell responses. PLOS ONE 2012, 7, e40733.

62. Allie, S.R.; Randall, T.D. Pulmonary immunity to viruses. Clin. Sci. 2017, 131, 1737-1762. [CrossRef] [PubMed]

63. Moyron-Quiroz, J.E.; Rangel-Moreno, J.; Hartson, L.; Kusser, K.; Tighe, M.P.; Klonowski, K.D.; Lefrançois, L.; Cauley, L.S.; Harmsen, A.G.; Lund, F.E.; et al. Persistence and responsiveness of immunologic memory in the absence of secondary lymphoid organs. Immunity 2006, 25, 643-654. [CrossRef]

64. Son, Y.M.; Cheon, I.S.; Wu, Y.; Li, C.; Wang, Z.; Gao, X.; Chen, Y.; Takahashi, Y.; Fu, Y.X.; Dent, A.L.; et al. Tissue-resident CD4(+) $\mathrm{T}$ helper cells assist the development of protective respiratory B and CD8(+) T cell memory responses. Sci. Immunol. 2021, 6, eabb6852. [CrossRef] [PubMed]

65. Adachi, Y.; Onodera, T.; Yamada, Y.; Daio, R.; Tsuiji, M.; Inoue, T.; Kobayashi, K.; Kurosaki, T.; Ato, M.; Takahashi, Y. Distinct germinal center selection at local sites shapes memory B cell response to viral escape. J. Exp. Med. 2015, 212, 1709-1723. [CrossRef] [PubMed]

66. Allie, S.R.; Randall, T.D. Resident Memory B Cells. Viral Immunol. 2020, 33, 282-293. [CrossRef]

67. Dogan, I.; Bertocci, B.; Vilmont, V.; Delbos, F.; Mégret, J.; Storck, S.; Reynaud, C.A.; Weill, J.C. Multiple layers of B cell memory with different effector functions. Nat. Immunol. 2009, 10, 1292-1299. [CrossRef] [PubMed]

68. McHeyzer-Williams, L.J.; Milpied, P.J.; Okitsu, S.L.; McHeyzer-Williams, M.G. Class-switched memory B cells remodel BCRs within secondary germinal centers. Nat. Immunol. 2015, 16, 296-305. [CrossRef]

69. Pape, K.A.; Taylor, J.J.; Maul, R.W.; Gearhart, P.J.; Jenkins, M.K. Different B cell populations mediate early and late memory during an endogenous immune response. Science 2011, 331, 1203-1207. [CrossRef]

70. Tarlinton, D. Antigen presentation by memory B cells: The sting is in the tail. Science 1997, 276, 374-375. [CrossRef]

71. Barker, K.A.; Etesami, N.S.; Shenoy, A.T.; Arafa, E.I.; Lyon de Ana, C.; Smith, N.M.; Martin, I.M.; Goltry, W.N.; Barron, A.M.; Browning, J.L.; et al. Lung-resident memory B cells protect against bacterial pneumonia. J. Clin. Investig. 2021, 131, e141810. [CrossRef]

72. Beura, L.K.; Fares-Frederickson, N.J.; Steinert, E.M.; Scott, M.C.; Thompson, E.A.; Fraser, K.A.; Schenkel, J.M.; Vezys, V.; Masopust, D. CD4(+) resident memory T cells dominate immunosurveillance and orchestrate local recall responses. J. Exp. Med. 2019, 216, 1214-1229. [CrossRef] [PubMed]

73. Kumar, B.V.; Ma, W.; Miron, M.; Granot, T.; Guyer, R.S.; Carpenter, D.J.; Senda, T.; Sun, X.; Ho, S.H.; Lerner, H.; et al. Human Tissue-Resident Memory T Cells Are Defined by Core Transcriptional and Functional Signatures in Lymphoid and Mucosal Sites. Cell Rep. 2017, 20, 2921-2934. [CrossRef] [PubMed]

74. Oja, A.E.; Piet, B.; Helbig, C.; Stark, R.; van der Zwan, D.; Blaauwgeers, H.; Remmerswaal, E.B.M.; Amsen, D.; Jonkers, R.E.; Moerland, P.D.; et al. Trigger-happy resident memory CD4(+) T cells inhabit the human lungs. Mucosal Immunol. 2018, 11, 654-667. [CrossRef] [PubMed]

75. Schreiner, D.; King, C.G. CD4+ Memory T Cells at Home in the Tissue: Mechanisms for Health and Disease. Front. Immunol. 2018, 9, 2394. [CrossRef] [PubMed]

76. Pruner, K.B.; Pepper, M. Local memory CD4 T cell niches in respiratory viral infection. J. Exp. Med. 2021, 218, e20201733. [CrossRef] 
77. Turner, D.L.; Bickham, K.L.; Thome, J.J.; Kim, C.Y.; D’Ovidio, F.; Wherry, E.J.; Farber, D.L. Lung niches for the generation and maintenance of tissue-resident memory T cells. Mucosal Immunol. 2014, 7, 501-510. [CrossRef]

78. Teijaro, J.R.; Turner, D.; Pham, Q.; Wherry, E.J.; Lefrançois, L.; Farber, D.L. Cutting edge: Tissue-retentive lung memory CD4 T cells mediate optimal protection to respiratory virus infection. J. Immunol. 2011, 187, 5510-5514. [CrossRef] [PubMed]

79. Glennie, N.D.; Volk, S.W.; Scott, P. Skin-resident CD4+ T cells protect against Leishmania major by recruiting and activating inflammatory monocytes. PLoS Pathog. 2017, 13, e1006349. [CrossRef] [PubMed]

80. Glennie, N.D.; Yeramilli, V.A.; Beiting, D.P.; Volk, S.W.; Weaver, C.T.; Scott, P. Skin-resident memory CD4+ T cells enhance protection against Leishmania major infection. J. Exp. Med. 2015, 212, 1405-1414. [CrossRef]

81. Romagnoli, P.A.; Fu, H.H.; Qiu, Z.; Khairallah, C.; Pham, Q.M.; Puddington, L.; Khanna, K.M.; Lefrançois, L.; Sheridan, B.S. Differentiation of distinct long-lived memory CD4 T cells in intestinal tissues after oral Listeria monocytogenes infection. Mucosal Immunol. 2017, 10, 520-530. [CrossRef]

82. Sakai, S.; Kauffman, K.D.; Schenkel, J.M.; McBerry, C.C.; Mayer-Barber, K.D.; Masopust, D.; Barber, D.L. Cutting edge: Control of Mycobacterium tuberculosis infection by a subset of lung parenchyma-homing CD4 T cells. J. Immunol. 2014, 192, $2965-2969$. [CrossRef] [PubMed]

83. Sallin, M.A.; Sakai, S.; Kauffman, K.D.; Young, H.A.; Zhu, J.; Barber, D.L. Th1 Differentiation Drives the Accumulation of Intravascular, Non-protective CD4 T Cells during Tuberculosis. Cell Rep. 2017, 18, 3091-3104. [CrossRef] [PubMed]

84. Chapman, T.J.; Topham, D.J. Identification of a unique population of tissue-memory CD4+ T cells in the airways after influenza infection that is dependent on the integrin VLA-1. J. Immunol. 2010, 184, 3841-3849. [CrossRef] [PubMed]

85. Rahimi, R.A.; Nepal, K.; Cetinbas, M.; Sadreyev, R.I.; Luster, A.D. Distinct functions of tissue-resident and circulating memory Th2 cells in allergic airway disease. J. Exp. Med. 2020, 217, e20190865. [CrossRef] [PubMed]

86. Steinfelder, S.; Rausch, S.; Michael, D.; Kühl, A.A.; Hartmann, S. Intestinal helminth infection induces highly functional resident memory CD4(+) T cells in mice. Eur. J. Immunol. 2017, 47, 353-363. [CrossRef]

87. Park, C.O.; Fu, X.; Jiang, X.; Pan, Y.; Teague, J.E.; Collins, N.; Tian, T.; O’Malley, J.T.; Emerson, R.O.; Kim, J.H.; et al. Staged development of long-lived T-cell receptor alphabeta TH17 resident memory T-cell population to Candida albicans after skin infection. J. Allergy Clin. Immunol. 2018, 142, 647-662. [CrossRef]

88. Ogongo, P.; Tezera, L.B.; Ardain, A.; Nhamoyebonde, S.; Ramsuran, D.; Singh, A.; Ng'oepe, A.; Karim, F.; Naidoo, T.; Khan, K.; et al. Tissue-resident-like CD4+ T cells secreting IL-17 control Mycobacterium tuberculosis in the human lung. J. Clin. Investig. 2021, 131, e142014. [CrossRef]

89. Ichikawa, T.; Hirahara, K.; Kokubo, K.; Kiuchi, M.; Aoki, A.; Morimoto, Y.; Kumagai, J.; Onodera, A.; Mato, N.; Tumes, D.J.; et al. CD103(hi) T(reg) cells constrain lung fibrosis induced by CD103(lo) tissue-resident pathogenic CD4 T cells. Nat. Immunol. 2019, 20, 1469-1480. [CrossRef] [PubMed]

90. Arpaia, N.; Green, J.A.; Moltedo, B.; Arvey, A.; Hemmers, S.; Yuan, S.; Treuting, P.M.; Rudensky, A.Y. A Distinct Function of Regulatory T Cells in Tissue Protection. Cell 2015, 162, 1078-1089. [CrossRef]

91. McKinstry, K.K.; Strutt, T.M.; Bautista, B.; Zhang, W.; Kuang, Y.; Cooper, A.M.; Swain, S.L. Effector CD4 T-cell transition to memory requires late cognate interactions that induce autocrine IL-2. Nat. Commun. 2014, 5, 5377. [CrossRef]

92. Hondowicz, B.D.; An, D.; Schenkel, J.M.; Kim, K.S.; Steach, H.R.; Krishnamurty, A.T.; Keitany, G.J.; Garza, E.N.; Fraser, K.A.; Moon, J.J.; et al. Interleukin-2-Dependent Allergen-Specific Tissue-Resident Memory Cells Drive Asthma. Immunity 2016, 44, 155-166. [CrossRef]

93. Hondowicz, B.D.; Kim, K.S.; Ruterbusch, M.J.; Keitany, G.J.; Pepper, M. IL-2 is required for the generation of viral-specific CD4(+) Th1 tissue-resident memory cells and B cells are essential for maintenance in the lung. Eur. J. Immunol. 2018, 48, 80-86. [CrossRef]

94. Kang, M.C.; Choi, D.H.; Choi, Y.W.; Park, S.J.; Namkoong, H.; Park, K.S.; Ahn, S.S.; Surh, C.D.; Yoon, S.W.; Kim, D.J.; et al. Intranasal Introduction of Fc-Fused Interleukin-7 Provides Long-Lasting Prophylaxis against Lethal Influenza Virus Infection. J. Virol. 2015, 90, 2273-2284. [CrossRef] [PubMed]

95. Strutt, T.M.; Dhume, K.; Finn, C.M.; Hwang, J.H.; Castonguay, C.; Swain, S.L.; McKinstry, K.K. IL-15 supports the generation of protective lung-resident memory CD4 T cells. Mucosal Immunol. 2018, 11, 668-680. [CrossRef]

96. Takamura, S. Niches for the Long-Term Maintenance of Tissue-Resident Memory T Cells. Front. Immunol. 2018, 9, 1214. [CrossRef] [PubMed]

97. Collins, N.; Jiang, X.; Zaid, A.; Macleod, B.L.; Li, J.; Park, C.O.; Haque, A.; Bedoui, S.; Heath, W.R.; Mueller, S.N.; et al. Skin $\mathrm{CD} 4(+)$ memory T cells exhibit combined cluster-mediated retention and equilibration with the circulation. Nat. Commun. 2016, 7 , 11514. [CrossRef] [PubMed]

98. Gebhardt, T.; Whitney, P.G.; Zaid, A.; Mackay, L.K.; Brooks, A.G.; Heath, W.R.; Carbone, F.R.; Mueller, S.N. Different patterns of peripheral migration by memory CD4+ and CD8+ T cells. Nature 2011, 477, 216-219. [CrossRef] [PubMed]

99. Gondek, D.C.; Olive, A.J.; Stary, G.; Starnbach, M.N. CD4+ T cells are necessary and sufficient to confer protection against Chlamydia trachomatis infection in the murine upper genital tract. J. Immunol. 2012, 189, 2441-2449. [CrossRef]

100. Johnson, R.M.; Brunham, R.C. Tissue-Resident T Cells as the Central Paradigm of Chlamydia Immunity. Infect. Immun. 2016, 84, 868-873. [CrossRef]

101. Johnson, R.M.; Yu, H.; Strank, N.O.; Karunakaran, K.; Zhu, Y.; Brunham, R.C. B Cell Presentation of Chlamydia Antigen Selects Out Protective CD4 $\gamma 13$ T Cells: Implications for Genital Tract Tissue-Resident Memory Lymphocyte Clusters. Infect. Immun. 2018, 86, e00614-e00617. [CrossRef] 
102. Iijima, N.; Linehan, M.M.; Zamora, M.; Butkus, D.; Dunn, R.; Kehry, M.R.; Laufer, T.M.; Iwasaki, A. Dendritic cells and B cells maximize mucosal Th1 memory response to herpes simplex virus. J. Exp. Med. 2008, 205, 3041-3052. [CrossRef] [PubMed]

103. Hwang, J.Y.; Randall, T.D.; Silva-Sanchez, A. Inducible Bronchus-Associated Lymphoid Tissue: Taming Inflammation in the Lung. Front. Immunol. 2016, 7, 258. [CrossRef] [PubMed]

104. Swarnalekha, N.; Schreiner, D.; Litzler, L.C.; Iftikhar, S.; Kirchmeier, D.; Kunzli, M.; Son, Y.M.; Sun, J.; Moreira, E.A.; King, C.G. T resident helper cells promote humoral responses in the lung. Sci. Immunol. 2021, 6, eabb6808. [CrossRef] [PubMed]

105. Yoshizawa, A.; Bi, K.; Keskin, D.B.; Zhang, G.; Reinhold, B.; Reinherz, E.L. TCR-pMHC encounter differentially regulates transcriptomes of tissue-resident CD8 T cells. Eur. J. Immunol. 2018, 48, 128-150. [CrossRef]

106. Crotty, S. Follicular helper CD4 T cells (TFH). Annu. Rev. Immunol. 2011, 29, 621-663. [CrossRef]

107. Schmitt, N.; Bustamante, J.; Bourdery, L.; Bentebibel, S.E.; Boisson-Dupuis, S.; Hamlin, F.; Tran, M.V.; Blankenship, D.; Pascual, V.; Savino, D.A.; et al. IL-12 receptor $\beta 1$ deficiency alters in vivo T follicular helper cell response in humans. Blood 2013, 121, 3375-3385. [CrossRef]

108. Johnston, R.J.; Choi, Y.S.; Diamond, J.A.; Yang, J.A.; Crotty, S. STAT5 is a potent negative regulator of TFH cell differentiation. J. Exp. Med. 2012, 209, 243-250. [CrossRef]

109. Ballesteros-Tato, A.; Leon, B.; Graf, B.A.; Moquin, A.; Adams, P.S.; Lund, F.E.; Randall, T.D. Interleukin-2 inhibits germinal center formation by limiting $\mathrm{T}$ follicular helper cell differentiation. Immunity 2012, 36, 847-856. [CrossRef]

110. DiToro, D.; Winstead, C.J.; Pham, D.; Witte, S.; Andargachew, R.; Singer, J.R.; Wilson, C.G.; Zindl, C.L.; Luther, R.J.; Silberger, D.J.; et al. Differential IL-2 expression defines developmental fates of follicular versus nonfollicular helper T cells. Science 2018, 361, eaao2933. [CrossRef]

111. Ise, W.; Fujii, K.; Shiroguchi, K.; Ito, A.; Kometani, K.; Takeda, K.; Kawakami, E.; Yamashita, K.; Suzuki, K.; Okada, T.; et al. T Follicular Helper Cell-Germinal Center B Cell Interaction Strength Regulates Entry into Plasma Cell or Recycling Germinal Center Cell Fate. Immunity 2018, 48, 702-715.e4. [CrossRef] [PubMed]

112. Suan, D.; Kräutler, N.J.; Maag, J.L.V.; Butt, D.; Bourne, K.; Hermes, J.R.; Avery, D.T.; Young, C.; Statham, A.; Elliott, M.; et al. CCR6 Defines Memory B Cell Precursors in Mouse and Human Germinal Centers, Revealing Light-Zone Location and Predominant Low Antigen Affinity. Immunity 2017, 47, 1142-1153.e4. [CrossRef]

113. Wang, Y.; Shi, J.; Yan, J.; Xiao, Z.; Hou, X.; Lu, P.; Hou, S.; Mao, T.; Liu, W.; Ma, Y.; et al. Germinal-center development of memory B cells driven by IL-9 from follicular helper T cells. Nat. Immunol. 2017, 18, 921-930. [CrossRef]

114. Shinnakasu, R.; Inoue, T.; Kometani, K.; Moriyama, S.; Adachi, Y.; Nakayama, M.; Takahashi, Y.; Fukuyama, H.; Okada, T.; Kurosaki, T. Regulated selection of germinal-center cells into the memory B cell compartment. Nat. Immunol. 2016, 17, 861-869. [CrossRef] [PubMed]

115. Phares, T.W.; Stohlman, S.A.; Hwang, M.; Min, B.; Hinton, D.R.; Bergmann, C.C. CD4 T cells promote CD8 T cell immunity at the priming and effector site during viral encephalitis. J. Virol. 2012, 86, 2416-2427. [CrossRef] [PubMed]

116. Janssen, E.M.; Droin, N.M.; Lemmens, E.E.; Pinkoski, M.J.; Bensinger, S.J.; Ehst, B.D.; Griffith, T.S.; Green, D.R.; Schoenberger, S.P. CD4+ T-cell help controls CD8+ T-cell memory via TRAIL-mediated activation-induced cell death. Nature 2005, 434, 88-93. [CrossRef] [PubMed]

117. Bevan, M.J. Helping the CD8(+) T-cell response. Nat. Rev. Immunol. 2004, 4, 595-602. [CrossRef]

118. Smith, C.M.; Wilson, N.S.; Waithman, J.; Villadangos, J.A.; Carbone, F.R.; Heath, W.R.; Belz, G.T. Cognate CD4(+) T cell licensing of dendritic cells in CD8(+) T cell immunity. Nat. Immunol. 2004, 5, 1143-1148. [CrossRef]

119. Swain, S.L.; McKinstry, K.K.; Strutt, T.M. Expanding roles for CD4 ${ }^{+}$T cells in immunity to viruses. Nat. Rev. Immunol. 2012, 12, 136-148. [CrossRef] [PubMed]

120. Oh, S.; Perera, L.P.; Terabe, M.; Ni, L.; Waldmann, T.A.; Berzofsky, J.A. IL-15 as a mediator of CD4+ help for CD8+ T cell longevity and avoidance of TRAIL-mediated apoptosis. Proc. Natl. Acad. Sci. USA 2008, 105, 5201-5206. [CrossRef] [PubMed]

121. Williams, M.A.; Tyznik, A.J.; Bevan, M.J. Interleukin-2 signals during priming are required for secondary expansion of CD8+ memory T cells. Nature 2006, 441, 890-893. [CrossRef]

122. Johnson, S.; Zhan, Y.; Sutherland, R.M.; Mount, A.M.; Bedoui, S.; Brady, J.L.; Carrington, E.M.; Brown, L.E.; Belz, G.T.; Heath, W.R.; et al. Selected Toll-like receptor ligands and viruses promote helper-independent cytotoxic $\mathrm{T}$ cell priming by upregulating CD40L on dendritic cells. Immunity 2009, 30, 218-227. [CrossRef] [PubMed]

123. Mitchell, D.M.; Ravkov, E.V.; Williams, M.A. Distinct roles for IL-2 and IL-15 in the differentiation and survival of CD8+ effector and memory T cells. J. Immunol. 2010, 184, 6719-6730. [CrossRef] [PubMed]

124. Kalia, V.; Sarkar, S. Regulation of Effector and Memory CD8 T Cell Differentiation by IL-2-A Balancing Act. Front. Immunol. 2018, 9, 2987. [CrossRef] [PubMed]

125. Laidlaw, B.J.; Cui, W.; Amezquita, R.A.; Gray, S.M.; Guan, T.; Lu, Y.; Kobayashi, Y.; Flavell, R.A.; Kleinstein, S.H.; Craft, J.; et al. Production of IL-10 by CD4(+) regulatory T cells during the resolution of infection promotes the maturation of memory CD8(+) $\mathrm{T}$ cells. Nat. Immunol. 2015, 16, 871-879. [CrossRef]

126. Bourgeois, C.; Rocha, B.; Tanchot, C. A role for CD40 expression on CD8+ T cells in the generation of CD8+ T cell memory. Science 2002, 297, 2060-2063. [CrossRef] [PubMed]

127. Badovinac, V.P.; Messingham, K.A.; Griffith, T.S.; Harty, J.T. TRAIL deficiency delays, but does not prevent, erosion in the quality of "helpless" memory CD8 T cells. J. Immunol. 2006, 177, 999-1006. [CrossRef] [PubMed] 
128. Nakanishi, Y.; Lu, B.; Gerard, C.; Iwasaki, A. CD8(+) T lymphocyte mobilization to virus-infected tissue requires CD4(+) T-cell help. Nature 2009, 462, 510-513. [CrossRef]

129. Laidlaw, B.J.; Zhang, N.; Marshall, H.D.; Staron, M.M.; Guan, T.; Hu, Y.; Cauley, L.S.; Craft, J.; Kaech, S.M. CD4+ T cell help guides formation of CD103+ lung-resident memory CD8+ T cells during influenza viral infection. Immunity 2014, 41, 633-645. [CrossRef]

130. Hutloff, A. T Follicular Helper-Like Cells in Inflamed Non-Lymphoid Tissues. Front. Immunol. 2018, 9, 1707. [CrossRef]

131. Yoshitomi, H.; Ueno, H. Shared and distinct roles of T peripheral helper and T follicular helper cells in human diseases. Cell Mol. Immunol. 2021, 18, 523-527. [CrossRef]

132. Rao, D.A.; Gurish, M.F.; Marshall, J.L.; Slowikowski, K.; Fonseka, C.Y.; Liu, Y.; Donlin, L.T.; Henderson, L.A.; Wei, K.; Mizoguchi, F.; et al. Pathologically expanded peripheral T helper cell subset drives B cells in rheumatoid arthritis. Nature 2017, 542, 110-114. [CrossRef] [PubMed]

133. Manzo, A.; Vitolo, B.; Humby, F.; Caporali, R.; Jarrossay, D.; Dell'accio, F.; Ciardelli, L.; Uguccioni, M.; Montecucco, C.; Pitzalis, C. Mature antigen-experienced T helper cells synthesize and secrete the B cell chemoattractant CXCL13 in the inflammatory environment of the rheumatoid joint. Arthritis Rheum. 2008, 58, 3377-3387. [CrossRef] [PubMed]

134. Kobayashi, S.; Murata, K.; Shibuya, H.; Morita, M.; Ishikawa, M.; Furu, M.; Ito, H.; Ito, J.; Matsuda, S.; Watanabe, T.; et al. A distinct human CD4+ T cell subset that secretes CXCL13 in rheumatoid synovium. Arthritis Rheum. 2013, 65, 3063-3072. [CrossRef] [PubMed]

135. Rubin, S.J.S.; Bai, L.; Haileselassie, Y.; Garay, G.; Yun, C.; Becker, L.; Streett, S.E.; Sinha, S.R.; Habtezion, A. Mass cytometry reveals systemic and local immune signatures that distinguish inflammatory bowel diseases. Nat. Commun. 2019, 10, 2686. [CrossRef]

136. Pitzalis, C.; Jones, G.W.; Bombardieri, M.; Jones, S.A. Ectopic lymphoid-like structures in infection, cancer and autoimmunity. Nat. Rev. Immunol. 2014, 14, 447-462. [CrossRef]

137. Coquet, J.M.; Schuijs, M.J.; Smyth, M.J.; Deswarte, K.; Beyaert, R.; Braun, H.; Boon, L.; Karlsson Hedestam, G.B.; Nutt, S.L.; Hammad, H.; et al. Interleukin-21-Producing CD4(+) T Cells Promote Type 2 Immunity to House Dust Mites. Immunity 2015, 43, 318-330. [CrossRef]

138. Vu Van, D.; Beier, K.C.; Pietzke, L.J.; Al Baz, M.S.; Feist, R.K.; Gurka, S.; Hamelmann, E.; Kroczek, R.A.; Hutloff, A. Local T/B cooperation in inflamed tissues is supported by T follicular helper-like cells. Nat. Commun. 2016, 7, 10875. [CrossRef]

139. Ren, H.M.; Kolawole, E.M.; Ren, M.; Jin, G.; Netherby-Winslow, C.S.; Wade, Q.; Shwetank Rahman, Z.S.M.; Evavold, B.D.; Lukacher, A.E. IL-21 from high-affinity CD4 T cells drives differentiation of brain-resident CD8 T cells during persistent viral infection. Sci. Immunol. 2020, 5, eabb5590. [CrossRef]

140. Flerlage, T.; Boyd, D.F.; Meliopoulos, V.; Thomas, P.G.; Schultz-Cherry, S. Influenza virus and SARS-CoV-2. pathogenesis and host responses in the respiratory tract. Nat. Rev. Microbiol. 2021, 19, 425-441. [CrossRef]

141. Sano, K.; Ainai, A.; Suzuki, T.; Hasegawa, H. The road to a more effective influenza vaccine: Up to date studies and future prospects. Vaccine 2017, 35, 5388-5395. [CrossRef]

142. Hellfritzsch, M.; Scherließ, R. Mucosal Vaccination via the Respiratory Tract. Pharmaceutics 2019, 11, 375. [CrossRef]

143. Pilkington, E.H.; Suys, E.J.A.; Trevaskis, N.L.; Wheatley, A.K.; Zukancic, D.; Algarni, A.; Al-Wassiti, H.; Davis, T.P.; Pouton, C.W.; Kent, S.J.; et al. From influenza to COVID-19: Lipid nanoparticle mRNA vaccines at the frontiers of infectious diseases. Acta Biomater. 2021, 131, 16-40. [CrossRef]

144. Wang, R.; Liu, M.; Liu, J. The Association between Influenza Vaccination and COVID-19 and Its Outcomes: A Systematic Review and Meta-Analysis of Observational Studies. Vaccines 2021, 9, 529. [CrossRef] [PubMed]

145. Estrada, L.D.; Schultz-Cherry, S. Development of a Universal Influenza Vaccine. J. Immunol. 2019, 202, 392-398. [CrossRef]

146. Sandbrink, J.B.; Shattock, R.J. RNA Vaccines: A Suitable Platform for Tackling Emerging Pandemics? Front. Immunol. 2020, 11, 608460. [CrossRef]

147. Liu, C.; Ginn, H.M.; Dejnirattisai, W.; Supasa, P.; Wang, B.; Tuekprakhon, A.; Nutalai, R.; Zhou, D.; Mentzer, A.J.; Zhao, Y.; et al. Reduced neutralization of SARS-CoV-2 B.1.617 by vaccine and convalescent serum. Cell 2021, 184, 4220-4236.e13. [CrossRef]

148. Planas, D.; Veyer, D.; Baidaliuk, A.; Staropoli, I.; Guivel-Benhassine, F.; Rajah, M.M.; Planchais, C.; Porrot, F.; Robillard, N.; Puech, J.; et al. Reduced sensitivity of SARS-CoV-2 variant Delta to antibody neutralization. Nature 2021, 596, 276-280. [CrossRef] [PubMed]

149. Wu, Y.; Goplen, N.P.; Sun, J. Aging and respiratory viral infection: From acute morbidity to chronic sequelae. Cell Biosci. 2021, 11, 112. [CrossRef] [PubMed]

150. Goplen, N.P.; Wu, Y.; Son, Y.M.; Li, C.; Wang, Z.; Cheon, I.S.; Jiang, L.; Zhu, B.; Ayasoufi, K.; Chini, E.N.; et al. Tissue-resident CD8(+) T cells drive age-associated chronic lung sequelae after viral pneumonia. Sci. Immunol. 2020, 5, eabc4557. [CrossRef] [PubMed] 